\title{
Does cultural proximity contain terrorism diffusion?
}

\author{
Tobias Böhmelt \\ Department of Government, University of Essex \\ Vincenzo Bove \\ Department of Politics and International Studies, University of Warwick
}

\begin{abstract}
What are the security consequences of population movements? This article seeks to provide a better understanding of when, how, and under what conditions terrorism diffuses across countries via migration flows as a vehicle. We contribute to this debate by studying the influence of migrants' cultural proximity to the native population of their host country. It is argued that cultural closeness can contain such terrorism diffusion. Similarities in societal norms, customs, or beliefs seem likely to induce trust in the social interactions between migrants and locals. This, in turn, makes it more difficult for terrorist organizations to exploit transnational population movements for radicalization and as a recruitment pool - one of the core mechanisms linking population flows with terrorism. Conversely, migrants from culturally distant societies may find it more challenging to integrate into their new homes. A fertile ground for terrorist organizations for the recruitment of new followers is thereby more likely. Our analyses present consistent evidence that the effect of terrorism diffusing across countries weakens when accounting for cultural closeness between migrants and host societies. This key finding of our research has crucial implications for policy's and scholars' understanding of terrorism, the diffusion of terrorism across countries, and the security consequences of population movements.
\end{abstract}

Keywords: terrorism, diffusion, violence, migration, cultural proximity 


\section{Introduction}

The world's migrant population has grown by more than 40 percent during the past 15 years and, indeed, most states now have significantly more immigrants than in the 1990s (UN DESA, 2016). Not surprising, international migration has become one of the most salient contemporary policy issues and its consequences have attracted particular attention from policymakers and scholars alike. For instance, the literature generally agrees that host countries benefit from migration economically (Dustmann \& Frattini, 2014). However, we must not ignore some of the more difficult political consequences of population movements, including security concerns linked to migration. There is evidence that migrants can have an important role in global security politics (Greenhill, 2010) and act as a conduit for transnational action, such as third-party military intervention in civil wars (Bove \& Böhmelt, 2019). Transnational migration may also challenge the stability of receiving countries by making it harder for states to control their territory (e.g. Adamson, 2006, Helbling \& Leblang, 2019). Migration inflows may further affect the ethnic composition of host nations (e.g. Dowty \& Loescher, 1996) or could facilitate the traveling of weapons, combatants, and ideologies across borders (Lischer, 2015: Salehyan \& Gleditsch, 2006). Additionally, population movements are frequently targeted by combatants and terror organizations (Choi \& Salehyan, 2013) and they might provoke retaliatory cross-border incidents between neighbors (Salehyan, 2008).

The traditional focus in this literature focusing on the security implications of population movements has recently shifted toward the types of migrants and the surrounding contextual parameters, which drive the impact of migration in diverse ways (see also Skeldon, 2008). Bove \& Böhmelt (2016) find that a large number of immigrants increases the odds of terrorism in the host country only when migrants stem from terroristprone countries of origin. The underlying theoretical mechanism for this effect is that migrant communities tend to have common views, loyalties, as well as a strong sense of community, which form pre-existing networks that can - more easily than in the case of other groups - be exploited by terrorist organizations for radicalization and recruitment (Sageman, 2004, 2011). Following this research, several studies explore the conditions under which migrants can actually give rise to security threats in recipient states, in particular terrorism. Dreher et al. (2017) ask whether immigration affects the risk of terrorism and Böhmelt \& Bove (forthcoming) analyze to what extent national migration policies moderate the diffusion of terrorism.

The following article contributes to a better understanding of when, how, and under what conditions terrorism diffuses across countries via migration flows as a vehicle. Specifically, we investigate whether and how migrants' cultural proximity to the host society mitigates the diffusion of terrorism via population movements. Culture can be defined as a 'system of meaning and value shared by a community, informing its way of life, and enabling it to make sense of the world' (Cohen, 1996, 109). Cultural proximity potentially has the power to shape people's societal norms, customs, and beliefs. In light of this, theoretically, we offer a thorough account of the conditions under which migration can be a vehicle for terrorism to diffuse from one country to another by taking into account migrants' cultural closeness to the local population of the host state. Previous 
empirical research on immigration and security often treats immigrants as homogeneous populations, without fully considering the at times significant variation within migrant streams (see, e.g. Kubrin et al., 2018). Merely pointing to the dichotomy of 'all immigrants' vs. 'all natives' does not comprehensively incorporate the cultural diversity that may exist across and within such population groups (Ousey \& Kubrin, 2018). We overcome these limitations by directly modeling the rich diversity within migration flows, and between immigrants and native populations, as we incorporate the cultural proximity of foreign-born individuals to native populations into the relationship of migration flows and terrorism diffusion.

We develop the argument that diffusion of terrorism across countries via migration depends on the cultural closeness between immigrants' countries of origin and their destination state. A shared understanding and a cultural bond between migrants and natives, i.e. cultural proximity contribute to a common identity and increase the level of trust among individuals (see Guiso et al., 2006, Spolaore \& Wacziarg, 2016), which facilitates the integration of migrants into the host society. In turn, this should make it more difficult for terrorist organizations to exploit migrant communities for radicalization and as a recruitment pool - one of the key causal mechanisms that associate migration with terrorism (Sageman, 2004, 2011). Conversely, 'people of different cultures will have greater difficulty in interaction, in understanding, and valuation' (Carnevale \& Choi, 2000, 16), and larger cultural distances erode trust and social cohesion within societies, making it more difficult for migrants to integrate (Allport, 1954, Velasco González et al., 2008, Ghosn et al., 2019). These conditions of marginalization can, as we contend, fuel migrants' radicalization and make it easier for terrorist organizations to recruit individuals (Lyons-Padilla et al., 2015).

Despite the lack of extensive data on when immigrants are the perpetrators - or rather the victims of terrorist violence by, e.g. anti-migration groups in the destination country, - terrorist attacks are often carried out by native-born citizens 1 In addition to taking an active part in terrorist violence, there is a variety of indirect means of support that terrorist groups can obtain from immigrants. Immigration flows from terrorist-prone countries could amplify the interaction between and interdependence of terrorist organizations across countries. Social ties based on migration flows may also contribute to terrorism through the diffusion of ideologies and the exchange of information within migrant networks. Migration further increases the exposure of domestic groups to prospects for mobilization and can allow for the exchange of ideas, resources, and knowledge (Zimmermann \& Rosenau, 2009; Bove \& Böhmelt, 2016). We argue that regardless of whether the support is direct or more indirect, this is facilitated by the marginalization of migrant groups. In the words of Wenger \& Mauer (2009, 9), 'the failure of integration has an obvious, but pernicious consequence - unabated marginalization leaves diasporic communities vulnerable to exploitation by radicals.' In an interview, former jihadist David Vallat offers examples of how marginalization and lack of integration, particularly of French Muslims, imparted a sense on not being full citizens. The lack of economic and social assimilation

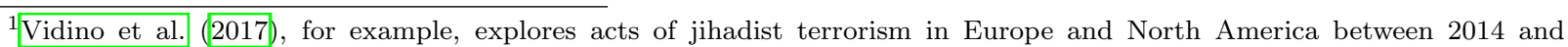
2017. They find that two-thirds of perpetrators were citizens of the country they attacked. Available online at: https: //tinyurl.com/y4lzmgbl 
of immigrants or those living in immigrant communities often promotes a vicious cycle of victimization: 'the recruitment process across the world capitalizes on the sense of marginalization young people feel and that creates a powerful rhetorical argument that the enemy is the state. ${ }^{2}$

As a result, we claim that cultural proximity between migrants and host countries can moderate the cross-national diffusion of terrorism via migrants. Our empirical results are based on quantitative, spatialeconometric analyses. We show that cultural closeness can indeed dampen the commonly perceived strong link between migration movements and the diffusion of terrorism: in fact, when directly considering cultural proximity for our estimations, there is little evidence that migration is linked to terrorism diffusion in significant ways. This main result carries important implications for policy's and scholars' understanding of terrorism.

\section{Terrorism diffusion via migration: The role of culture}

The economic, political, and social determinants of terrorism are widely studied (e.g. Enders et al., 2011, Young \& Findley, 2011; Wilson \& Piazza, 2013, Gaibulloev et al., 2017, Gaibulloev \& Sandler, 2018). In this literature, the diffusion of terrorism refers to a particular aspect, namely spatial links connecting countries to each other, which allow for the possibility that terrorism in one national context is influenced by terrorism in other states. Braithwaite \& Li (2007) shed light on the clustering of terrorist incidents in space as they identify 'hot spots' of terrorist attacks, i.e. areas in which terrorism occurs much more frequently than in others ${ }^{3}$ In addition, Neumayer \& Plümper (2010) report spatial dependence of international terrorism along civilizational lines, while Findley et al. (2012) examine the influence of state rivalries on terrorism traveling across borders. Blomberg \& Hess (2008) and Li \& Schaub (2004) focus on the impact of globalization on the diffusion of terrorism between state pairs, whereas Braithwaite \& Chu (2018) show that militants from civil wars abroad affect terrorism in other states.

Population movements are one form of spatial links that connect countries to each other, making it possible that one national context and its level of terrorism are affected by other countries and their degree of terrorist violence (e.g. Buhaug \& Gleditsch, 2008, Bove \& Böhmelt, 2016, Braithwaite \& Chu, 2018). However, we still lack systematic research on the diffusion of terrorism via migration that incorporates contextual factors and moderating conditions that could enhance or hamper terrorism travelling across borders. In the following, we add to this debate as we investigate one crucial aspect of population movements, which also allows us to move beyond the rather simplistic view of migrants as homogeneous populations: the cultural closeness of immigrants to their host countries. While migration can be a cross-national diffusion path and immigrants can be a vehicle (directly or indirectly) for terrorism to travel from one state to another, we contend that the cultural proximity between migrants' home and host countries matters and, in fact, can work against such

\footnotetext{
${ }^{2}$ Available online at: https://tinyurl.com/yx9zq84g.

${ }^{3}$ Similarly, Nemeth et al. (2014) uncover local areas more likely to experience domestic terrorism.
} 
diffusion of terrorism.

The economic literature has long argued that cultural diversity, the range of citizens with different origins, religions, and traditions living and interacting together, plays a pivotal (and mostly positive) role in shaping economic growth (Alesina \& Ferrara, 2005). Yet, depending on the circumstances, diversity can be associated with both normatively adversarial and beneficial effects. That is, although diversity can lead to positive organizational synergies, a larger cultural distance is often characterized by different norms practiced, different perceptions held, and more misunderstandings between, in our case, migrants and local populations Bakaki et al. 2016, Alesina \& Ferrara, 2005). Particularly relevant to our research, by potentially being culturally distant to the local population and eventually further affecting cultural diversity in host societies, immigration influences individual interactions in decisive ways: in fact, cultural barriers are usually seen as customary impediments to interpersonal trust, solidarity, and social capital (see, e.g. Guiso et al., 2006).

In line with this mechanism, several studies show that immigrants from countries that are culturally more similar to the host state are better able to integrate (e.g. De Wit \& Koopmans, 2005, Maxwell, 2010. Isphording, 2014). Conversely, cultural distance can be a major hurdle to social and economic interactions across groups (Gokmen, 2017). Immigrants with culturally more distant backgrounds who are more concerned over the preservation of their own identity are particularly less likely to assimilate (Dowty \& Loescher, 1996), fueling the fear of host societies that migration may threaten their existing cultural identity (Velasco González et al. 2008). And indeed, the cultural distance between social groups is likely to be a core driver of locals' negative attitudes and prejudice towards immigrants (e.g. Allport, 1954, Weiner, 1992, Mahfud et al., 2018). Clearly, cultural proximity does not by default lead to trust-building among immigrants and natives, but it serves as an important facilitating factor. When subscribing to the link between cultural proximity and trust, this bond might ease migrants' integration through, e.g. the social inclusion of migrants in receiving societies and improved labor market participation. Cultural closeness between migrants and the local population of the destination country is therefore likely to be a significant factor for the integration of immigrants (see also Angelini et al., 2015).

A larger cultural distance of migrants to the population of their new home could marginalize the former and aggravate their integration - which, in turn, leads to one of the main mechanisms associating migration flows with terrorism diffusion: radicalization and the recruitment of individuals by terrorist organizations (Sageman, 2004, 2011). That is, cultural identity plays an important role in the radicalization of individuals (for an overview, see, Lyons-Padilla et al., 2015). Immigrants who are culturally homeless lack a clear feeling of belonging and are more likely to become marginalized, making them to be more attracted to groups that offer a sense of inclusion, purpose, and identity. And this frequently constitutes the first step toward developing a radical belief system (Hogg, 2011, Doosje et al., 2013, Lyons-Padilla et al., 2015). Not surprisingly then, higher levels of prejudice toward immigrants have been associated with less cultural closeness between immigrants and the majority group (Mahfud et al. 2015). This may make it easier for 
marginalized communities to be attracted to groups offering a feeling of identity - and immigrants with a more culturally-distant background are not only more likely to feel a loss of significance, but are also then more susceptible to radicalization (Wenger \& Mauer, 2009, Lyons-Padilla et al., 2015). All this is facilitated by strong social bonds that usually connect individuals within migrant populations. Sageman (2004, 2011) contends here that these ties predating recruitment into terrorist organizations are the crucial element of this process (see also Bove \& Böhmelt, 2016): the existence of social bonds comes first and ideology follows (Sageman, 2004, 133). The process of joining terrorist groups is then 'through mutual emotional and social support, development of a common identity, and encouragement to adopt a new faith. All these factors are internal to the group' (Sageman, 2004, 135). Terrorist organizations can exploit these social linkages within migrant groups, particularly if migrants feel marginalized and excluded, for radicalization and to recruit members (Sageman, 2011).

Particularly when immigrants are not fully integrated in host societies, resentment and anger can facilitate their recruitment - or the recruitment of their children - by terrorism organizations (Schmid, 2016). For example, in both France and Belgium, many immigrants and their offspring live in deprived city neighborhoods, 'separated culturally but linked physically to the surrounding urban landscape,' sparking a heated debate on the link between terrorism and lack of assimilation ${ }^{4}$ Brussels' Molenbeek district, a melting pot of different nationalities, illustrates this. Many recent terrorism attacks across Europe have been linked to people residing in this area, and a main reason that has often been put forward for this is the lack of access to important services, particularly active integration programs for migrants, 5 Consider also Cherif Kouachi, involved with his brother in the 2015 Charlie Hebdo shooting. Raised in a northern suburb of Paris, he was driven by a sense of social estrangement. According to Mohammed Benali, president of the local mosque, he was of a 'generation that felt excluded, discriminated against and, most of all, humiliated. They spoke and felt French, but were regarded as Arabic; they were culturally confused.' Similarly, Mohammad Sidique Khan, the leader of the $7 / 7$ bombings in London (2005), was caught 'between no cultures' and expressed his rage through terrorist violence ${ }^{6}$ In contrast, the promotion of immigration and assimilation is regarded as the best deterrent against radicalizing people to join terrorist organizations.7

Marginalized migrants from terrorist-prone countries do not necessarily have a direct effect on terrorist activities by, e.g. taking an active part in terrorist attacks, but may support domestic terrorist group in the adopted country in an indirect way, which eventually heightens the level of terrorism. Migration can increase the exposure of domestic groups to prospects for mobilization, thus making emulation more likely

\footnotetext{
${ }^{4}$ Available online at: https://tinyurl.com/y23rk2gb

${ }^{5}$ For example, in Flanders, immigrants receive courses about Belgian values and languages, but the Flemish community does not offer such classes in Brussels. As such, the mainly Arabic and French-speaking residents of Molenbeek have trouble finding jobs in Brussels as even low-level service jobs require proficiency in Dutch. Available online at: https://tinyurl.com/yxzjjryt

${ }^{6}$ Available online at: https://tinyurl.com/y3xvllx5

${ }^{7}$ See online at: https://tinyurl.com/y2gdguqa. And in the words of Sageman (2011 96), 'although each continent has become a beacon for immigrants, their welcome varies greatly according to where they land. In America, the melting pot myth facilitates the assimilation of outsiders, while in Europe the emphasis on a national essence prevents the integration of immigrants that 'look different.' Assimilation makes it less likely for Muslim Americans to believe that they are part of a war against Islam, while exclusion on a basis of a national essence makes it more likely for Muslim Europeans to believe this notion.'
} 
to emerge (Adamson, 2006). Similarly, members of immigrant communities may allow for the exchange of ideas, as terrorist groups in the host country often lack the relevant experience to organize terrorist activities (Salehyan \& Gleditsch, 2006, Choi \& Salehyan, 2013). As such, the connection between foreign and domestic terrorist organizations mainly focuses on information exchange. Finally, migrant inflows could facilitate the establishment of transnational links between terrorist groups, which induce cooperation, the pooling of resources, and the access to knowledge that would be unavailable otherwise 8

Cultural proximity between immigrants and destination countries could offset this. We contend that this process is aggravated if migrants are not culturally distant from, but closer to the host society and, thereby, potentially more integrated and less marginalized. Cultural proximity between immigrants and natives is a crucial intervening factor that moderates the impact of migration on terrorism diffusion. On one hand, assimilation and integration are likely stronger when immigrants are culturally closer to the native population of the destination country. Integration promotes social, economic, and civic well-being (Vigdor, 2015). By reducing the odds of failed assimilation, cultural proximity also lowers feelings of personal uncertainty, injustice, and perceived intergroup threats that are among the key determinants of radicalization (see also Rahimi \& Graumans, 2015). On the other hand, cultural closeness can prevent the development of negative out-group attitudes (Wenger \& Mauer, 2009, Lyons-Padilla et al., 2015). To the extent that social integration matters for predicting a group's vulnerability to terrorist recruitment (Zimmermann \& Rosenau, 2009, Sageman, 2004, 2011), and subscribing to the claim that cultural proximity facilitates assimilation and integration, terrorist groups should find it more challenging to radicalize and recruit followers under those circumstances. This should weaken the effect of migration as a vehicle for the diffusion of terrorism. Hence, cultural proximity of migrants to their host country contains, and acts as a barrier to, the diffusion of terrorism via population movements. This leads to the following hypothesis:

Hypothesis: Cultural proximity weakens the diffusion of terrorism across countries.

\section{Research design}

\section{Data}

We created a monadic (country-year as the unit of analysis) panel data set comprising OECD countries from 1980 to 2010. We concentrate on OECD states as possible destinations for migrants, but allow for migration flows from anywhere in the world (see below). In other words, non-OECD states are not considered as destinations of migration movements in our study, but all countries worldwide between are possible origins of migration flows. Focusing on OECD host countries has the benefit of examining a set of states that is

\footnotetext{
${ }^{8}$ At the same time, our argument does not imply that all migrant groups are at risk of being recruited by terrorist groups. In fact, this process can be divided in two stages. There are groups of migrants that will never be at risk for recruitment, regardless of some underlying characteristics, such as their ethnic, linguistic, or religious background. Yet, for those who are at risk of being targeted by terrorist organizations, high cultural distance from the host countries can facilitate this process and heighten the chances that terrorist organizations will gain vital support from marginalized and excluded individuals.
} 
rather homogeneous in a number of socio-economic and political characteristics, e.g. levels of democracy, development, and membership in international organizations. This helps to isolate the effects stemming from the spatial diffusion of terrorism. Furthermore, OECD countries are among the top destinations of international migration. As of 2015, more than half of the international-migrant population was hosted in the OECD region (see UN DESA, 2016).

For our dependent variable, we measure the level of terrorism at the country level each year using the Global Terrorism Database (GTD) that defines terrorism as 'the premeditated use or threat to use violence by individuals or sub-national groups against noncombatants in order to obtain a political or social objective through the intimidation of a large audience beyond that of the immediate victims' (Enders et al., 2011, 321). We do not distinguish between national and transnational attacks as our argument applies to both cases (see also Bove \& Böhmelt, 2016, Sageman, 2004, 2011) 9 Given the skewed distribution of the number of terrorist incidents, our final outcome variable is the log-transformed number of terrorist attacks in a given year after adding the value of 1 .

Data on migrant populations are taken from the World Bank (Özden et al., 2011, 17), which relies on two main criteria to define migration: being born in or being a citizen of a foreign country. That said, the place-of-birth definition is considered superior by the World Bank as 'while nationality can change, place of birth cannot'. And when data are available for both criteria, the World Bank gives priority to the birthplace (Özden et al. 2011, 17). Furthermore, Özden et al. (2011) subtract the number of refugees from total migrant numbers as the focus is mostly on economic migrants 10 The data are therefore consistent with our theoretical argument, which pertains to diaspora communities or people who are permanently settled in a country. Refugee flows are a temporary movement of people that flee violence to seek protection, but we focus on the longer time horizon of migrants as opposed to refugees. Moreover, case-specific narratives highlight that there is usually a longer period of radicalization and, hence, using the stock of immigrants rather than recent entrants is a more suitable approach (see also Dreher et al., 2017, 5). In addition, while migration is a phenomenon of global scope with a much wider reach, refugee flows are more localized, usually constrained to neighboring countries 11 The estimates are derived from national census and population register records for 232 destinations (countries and country-like territories), including our OECD states 12 As each census round was conducted during a 10-year window, we linearly interpolate all missing data between two consecutive rounds. After accounting for missing values and temporally lagging all our explanatory items, our sample comprises 32 potential host states from the OECD that we combine with more than 200 countries of origin to create bilateral matrices of migration populations between sender and receiver nations each year between

\footnotetext{
${ }^{9}$ We return to this issue in the Online appendix.

${ }^{10}$ According to Özden et al. $(2011,14)$, '[w] hile refugees are generally enumerated in developed country censuses, this is not always the case for developing countries. Refugees interned in camps are less likely to be surveyed at the time of census [...]. For the cases that rely on the Trends in International Migrant Stock database, the number of refugees is subtracted from the totals, with the intention of removing refugees in camps from the total.'

${ }^{11}$ However, the Online appendix summarizes a robustness check, which controls for refugee populations.

${ }^{12}$ Available online at: http://www.un.org/en/development/desa/population/migration/data/index.shtml.
} 
1980 and 2010 13 We use the data on migration for the construction of the spatial lags, which we describe in the methodology section.

A central challenge for our empirical study is that the estimates may be biased by endogeneity stemming from omitted variables. This becomes even more important for the spatial-econometric approach that we describe below as we must distinguish a genuine diffusion effect from mere country-level influences and spatial clustering (Franzese \& Hays, 2007, 2008, Plümper \& Neumayer, 2010, Buhaug \& Gleditsch, 2008). To mitigate this concern, we control for several relevant country attributes that are both spatially clustered and potentially related to terrorism (e.g. Enders et al. 2011; Krieger \& Meierrieks, 2011; Young \& Findley, 2011; Wilson \& Piazza, 2013: Gaibulloev et al., 2017; Gaibulloev \& Sandler, 2018), which allows us to accurately identify a real spatial diffusion effect - and it is our aim then to see how cultural proximity between migrants and host societies alters this. First, Gaibulloev et al. (2017, 15) recommend controlling for a state's involvement in foreign policy. To this end, we consider a variable on alliance ties with the US, which is binary and based on the Correlates of War Formal Alliance data set (Gibler, 2008).

Second, we include information on per-capita GDP and population as wealthier and less populous states are likely to experience significantly less terrorism ( $\mathrm{Li}, 2005$, Piazza, 2006). Both items are log-transformed and, as all other variables, lagged by one year. We also control for the level of democracy using the revised and combined polity score from the Polity IV database (Marshall \& Jaggers, 2015). The score potentially assumes values between -10 and +10 , while higher values denote more democratic forms of government.

Third, immigrants might select themselves into countries based on potential economic opportunities and the generosity of local migration policies, and this has long been a concern in the cross-country migration literature as it introduces selection bias. Income and democracy, therefore, not only control for alternative mechanisms of terrorism, but also should correlate with migration flows (e.g. Breunig et al., 2012, Alarian \& Goodman, 2017 Helbling et al. 2017). We further control the number of immigrants (in percentage of the population), and the level of immigration restrictions for the same reason. The number immigrants as a share of the total population in a given country-year disentangles the effect of the spatial variables we present in the next section from the impact of immigration alone, which is theoretically and empirically different. Migrants also select themselves into those destinations that already have larger diaspora communities.

Finally, as immigrants are more likely to move to countries with less stringent immigration policies in terms of, e.g. regulations or control mechanisms (e.g. Breunig et al., 2012, Alarian \& Goodman, 2017, Helbling \& Leblang, 2019), we include a control using the Immigration Policies in Comparison (IMPIC) data set (see Helbling et al. 2017) 14 These data offer information on the total level of restrictiveness of immigration policies across four dimensions for all OECD countries between 1980 and 2010. The data are presented on a scale between 0 and 1, where 1 is the maximum relative level of restrictiveness. We use the data's aggregated variable that combines internal and external regulations with control mechanisms.

\footnotetext{
${ }^{13}$ Due to data limitations, the OECD countries excluded from the analysis are Iceland, Latvia, Lithuania, and Slovenia.

${ }^{14}$ Available online at: http://www.impic-project.eu/
} 
Table I. Descriptive statistics: Dependent variable and controls

\begin{tabular}{lccccc}
\hline \multicolumn{1}{c}{ Variable } & Mean & Std. Dev. & Min. & Max. & Obs. \\
\hline Terrorism (ln) & 1.364 & 1.442 & 0 & 6.267 & 911 \\
Alliance with US & 0.682 & 0.466 & 0 & 1 & 911 \\
Democracy & 8.904 & 3.151 & -8 & 10 & 911 \\
GDP per capita (ln) & 9.943 & 0.696 & 7.972 & 11.382 & 911 \\
Population (ln) & 9.648 & 1.371 & 5.898 & 12.634 & 911 \\
Total migration population & 9.445 & 8.715 & 0.424 & 38.537 & 911 \\
Internal immigration policy restrictions & 0.512 & 0.089 & 0.314 & 0.812 & 911 \\
\hline
\end{tabular}

\section{Methodology}

We estimate spatial temporal autoregressive models based on ordinary least squares (spatial-OLS) and specify a weighting matrix on migrant-population movements and cultural proximity. The core part of this is $\mathbf{W} y_{t-1}$, which is the spatial variable comprising the product of a row-standardized connectivity matrix (W) with the temporally lagged dependent variable $\left(y_{t-1}\right){ }^{15}$ The elements $\left(w_{i, j}\right)$ in the weighting matrix measure the relative connectivity of country $j$ to country $i$ (with $w_{i, i}=0$ ). A positive and statistically significant effect constitutes a positive diffusion effect in that, in our case, terrorism in the sending state increases terrorism in the recipient country. A negative and statistically significant effect would capture a negative diffusion effect in that, in our case, more terrorism in the sending state decreases terrorism in the recipient country. Following Franzese \& Hays (2008, 2007, 142), we control for a number of relevant 'exogenous-external conditions or common shocks and spatially correlated unit level factors.' Next to the control variables we outlined above and the temporally lagged dependent variable, country effects are added to account for unobserved heterogeneities that are specific to each country and to leverage changes occurring within units. Time effects are entered to control for temporal shocks or systemic effects that might affect terrorism, such as the $9 / 11$ attacks.

The core of this methodological approach and, hence, our empirical analysis are three spatial lags. All spatial items are based on a matrix that links countries via migrant populations $\sqrt{16}$ That is, the elements of each variable's matrix measure for each pair of countries in a given year the size of the migrant population of a foreign state (country of origin) in the country under study (host state). While one (the first) spatial lag's underlying weights matrix is only based on migrant populations, the other two spatial lags rely on weighting matrices that further include information about cultural proximity and distance, respectively, between countries. Ultimately, for the first spatial lag that is only based on migration populations, each element $w_{i, j}$ of the connectivity matrix measures the migrant population in country $i$ that has country $j$ as the state of origin in $t$ - 1 . In the absence of any migration population from $j$ in $i, w_{i, j}$ takes the value of 0 . This row-standardized matrix is multiplied with the temporally lagged dependent variable $\left(y_{t-1}\right)$ to create the first spatial lag, which then measures the average degree of terrorism in other countries weighted by migrant populations. As indicated above, we take the data on migrant populations from Özden et al. (2011)

\footnotetext{
${ }^{15} \mathrm{~A}$ potential impact on terrorism via a migration-diffusion path plausibly requires some time to evolve; hence, we use the temporally lagged dependent variable.

${ }^{16}$ In the Online appendix, we provide more specific information on the construction of the spatial lags.
} 
and we expect a positive and significant effect for this first spatial lag.

The second spatial lag is similar to the first one except for an additional component added to the weighting matrix. That is, each element $w_{i, j}$ of the second connectivity matrix captures the migrant population in country $i$ that has country $j$ as the state of origin in $t-1$ - but only in culturally close countries. We measure cultural proximity between two countries $i, j$ in the matrix via the cultural-differences information in Kandogan (2012), which is a revised variable of the standardized measure of cultural distance as introduced in Kogut \& Singh (1988) ${ }^{17}$ For countries' cultural links in the connectivity matrix, we first paired each state with all other countries and then merged the Kandogan (2012) variable into this dyadic data set. We reversed the scale of that variable so that higher values pertain to more cultural similarities between states. Afterwards, we divided the item into ten equally sized groups (quantiles), while the five most similar groups eventually receive an entry of 1 in the elements $w_{i, j}$ of the connectivity matrix and the five least similar quantiles are coded as 0 for $w_{i, j}$. Finally, these entries $w_{i, j}$ are multiplied by the migrant population in country $i$ that has country $j$ as the state of origin in $t-1$ in order to capture migrant flows between $i$ and $j$, which are then two states that are by construction culturally more similar to each other.

Our final spatial lag combines information about migrant stocks and cultural dissimilarity in its underlying matrix. That is, using the reversed scale on cultural proximity (Kandogan, 2012$)$ and the ten equally sized groups, the five least similar quantiles are now coded as 1 in the elements $w_{i, j}$ of the connectivity matrix (all other entries as 0). As above, we multiply these entries with the migrant population in country $i$ that has country $j$ as the state of origin in $t$ - 1 , which then measures migrant populations across tow culturally dissimilar states. In light of our theory, we expect an insignificant estimate for the culturally-similar spatial lag, but a positive and significant impact stemming from our last spatial variable that focuses on culturally distant states. Table II summarizes the descriptive statistics of the spatial variables and the temporally lagged dependent variable. The weighted level of terrorism in all other countries is around 1.27, when the weights are based on migrant populations only. When focusing on migrant flows from culturally proximate countries, the value increases to 1.479 , while it is around 1.473 for migration from culturally distant states. In the following, we assess whether these items shape terrorism 'at home' in systematic ways.

Table II. Descriptive statistics: Spatial lags and lagged dependent variable

\begin{tabular}{lccccc}
\hline \multicolumn{1}{c}{ Variable } & Mean & Std. Dev. & Min. & Max. & Obs. \\
\hline Lagged dependent variable & 1.401 & 1.459 & 0 & 6.267 & 911 \\
Wy: Migrant inflow & 1.271 & 0.425 & 0.539 & 2.536 & 911 \\
Wy: Migrant inflow cultural proximity & 1.479 & 0.753 & 0 & 3.365 & 911 \\
Wy: Migrant inflow cultural distance & 1.473 & 0.575 & 0 & 3.06 & 911 \\
\hline
\end{tabular}

\footnotetext{
${ }^{17}$ The Online appendix describes the cultural-proximity data in more detail. Moreover, a robustness check is based on genetic closeness rather than cultural proximity.
} 


\section{Findings}

All models in Table III are identical in terms of controls and fixed effects, but they differ in the spatial variable(s) considered. Model 1 focuses on $\boldsymbol{W} y$ : Migrant inflow. Model 2 replaces that item by the spatial lag that is weighted by migration inflows and cultural proximity. Model 3 concentrates on terrorism weighted by migration in culturally distant states. Finally, Model 4 comprises both Wy: Migrant inflow cultural proximity and $\boldsymbol{W} y$ : Migrant inflow cultural distance. Due to the row standardization, the spatial lags can be interpreted directly. However, as we include a temporally lagged dependent variable, our coefficient estimates of the spatial lags only reflect the short-term effect, i.e. the impact in a current year. Asymptotic long-term influence of these items are calculated according to Plümper et al. (2005, 336) and discussed in the text where relevant.

Table III. Terrorism diffusion: The Role of cultural proximity

\begin{tabular}{|c|c|c|c|c|}
\hline & Model 1 & Model 2 & Model 3 & Model 4 \\
\hline Lagged dependent variable & $\begin{array}{c}0.475^{* *} \\
(0.030)\end{array}$ & $\begin{array}{c}0.474^{* *} \\
(0.030)\end{array}$ & $\begin{array}{c}0.477^{* *} \\
(0.030)\end{array}$ & $\begin{array}{c}0.475^{* *} \\
(0.030)\end{array}$ \\
\hline Wy: Migrant inflow & $\begin{array}{r}0.529^{\dagger} \\
(0.271)\end{array}$ & & & \\
\hline Wy: Migrant inflow cultural proximity & & $\begin{array}{c}0.074 \\
(0.093)\end{array}$ & & $\begin{array}{c}0.073 \\
(0.093)\end{array}$ \\
\hline Wy: Migrant inflow cultural distance & & & $\begin{array}{r}0.229^{\dagger} \\
(0.139)\end{array}$ & $\begin{array}{r}0.228^{\dagger} \\
(0.139)\end{array}$ \\
\hline Alliance with US & $\begin{array}{c}0.185 \\
(0.152)\end{array}$ & $\begin{array}{c}0.136 \\
(0.150)\end{array}$ & $\begin{array}{c}0.152 \\
(0.150)\end{array}$ & $\begin{array}{c}0.162 \\
(0.151)\end{array}$ \\
\hline Democracy & $\begin{array}{c}0.002 \\
(0.011)\end{array}$ & $\begin{array}{r}-0.003 \\
(0.011)\end{array}$ & $\begin{array}{r}-0.003 \\
(0.011)\end{array}$ & $\begin{array}{c}-0.002 \\
(0.011)\end{array}$ \\
\hline GDP per capita $(\ln )$ & $\begin{array}{r}-0.439^{*} \\
(0.214)\end{array}$ & $\begin{array}{r}-0.372^{\dagger} \\
(0.215)\end{array}$ & $\begin{array}{r}-0.389^{\dagger} \\
(0.210)\end{array}$ & $\begin{array}{r}-0.437^{*} \\
(0.218)\end{array}$ \\
\hline Population (ln) & $\begin{array}{c}1.213^{*} \\
(0.514)\end{array}$ & $\begin{array}{r}0.953^{\dagger} \\
(0.494)\end{array}$ & $\begin{array}{c}1.000^{*} \\
(0.493)\end{array}$ & $\begin{array}{c}1.047^{*} \\
(0.496)\end{array}$ \\
\hline Total migration population & $\begin{array}{c}0.012 \\
(0.018)\end{array}$ & $\begin{array}{c}0.006 \\
(0.018)\end{array}$ & $\begin{array}{c}0.003 \\
(0.018)\end{array}$ & $\begin{array}{c}0.004 \\
(0.018)\end{array}$ \\
\hline Internal immigration policy restrictions & $\begin{array}{c}0.293 \\
(0.502)\end{array}$ & $\begin{array}{c}0.222 \\
(0.508)\end{array}$ & $\begin{array}{c}0.223 \\
(0.499)\end{array}$ & $\begin{array}{c}0.303 \\
(0.509)\end{array}$ \\
\hline Constant & $\begin{array}{r}-11.346^{\dagger} \\
(6.660)\end{array}$ & $\begin{array}{r}-7.753 \\
(6.376)\end{array}$ & $\begin{array}{r}-8.516 \\
(6.389) \\
\end{array}$ & $\begin{array}{r}-8.838 \\
(6.403)\end{array}$ \\
\hline Observations & 911 & 911 & 911 & 911 \\
\hline Country fixed effects & Yes & Yes & Yes & Yes \\
\hline Year fixed effects & Yes & Yes & Yes & Yes \\
\hline Prob. $>$ F & 0.000 & 0.000 & 0.000 & 0.000 \\
\hline
\end{tabular}

Standard errors in parentheses.

$\dagger \mathrm{p}<0.10, * \mathrm{p}<0.05, * * \mathrm{p}<0.01$

First, Wy: Migrant inflow is positively signed and significant at the 10 percent level in Model 1 . This finding mirrors and replicates Bove \& Böhmelt (2016) in that it underlines that migration flows can be a vehicle for terrorism to diffuse from one state to another. We can rule out that this is driven by geographical proximity, since our analysis combines OECD-only host states with all other countries in the world. In substantive terms, the marginal effect in Model 1 suggests that a one-unit increase in Wy: Migrant inflow 
leads to a rise in terrorist attacks of about 1.67 events. As indicated above, this is merely the short-term effect, though. The asymptotic long-term marginal effect of this first spatial lag is about 0.968 (coefficient estimate), which translates into 2.6 attacks. While these results mirror existing findings on terrorism diffusion via population movements, therefore highlighting that the degree of terrorism 'at home' increases with migrants from countries with a high level of terrorism, the first model does not take into account that states might be linked via cultural ties to each other. In other words, our first estimation in Table III treats immigrants as homogeneous populations, merely pointing to the dichotomy of 'immigrants' vs. 'natives' without fully incorporating the cultural diversity that may exist across and within such populations (Ousey \& Kubrin, 2018, Kubrin et al., 2018). To this end, Models 2-4 concentrate on Wy: Migrant inflow cultural proximity and $\boldsymbol{W}$ : Migrant inflow cultural distance.

Figure 1. Terrorism diffusion: The role of cultural proximity

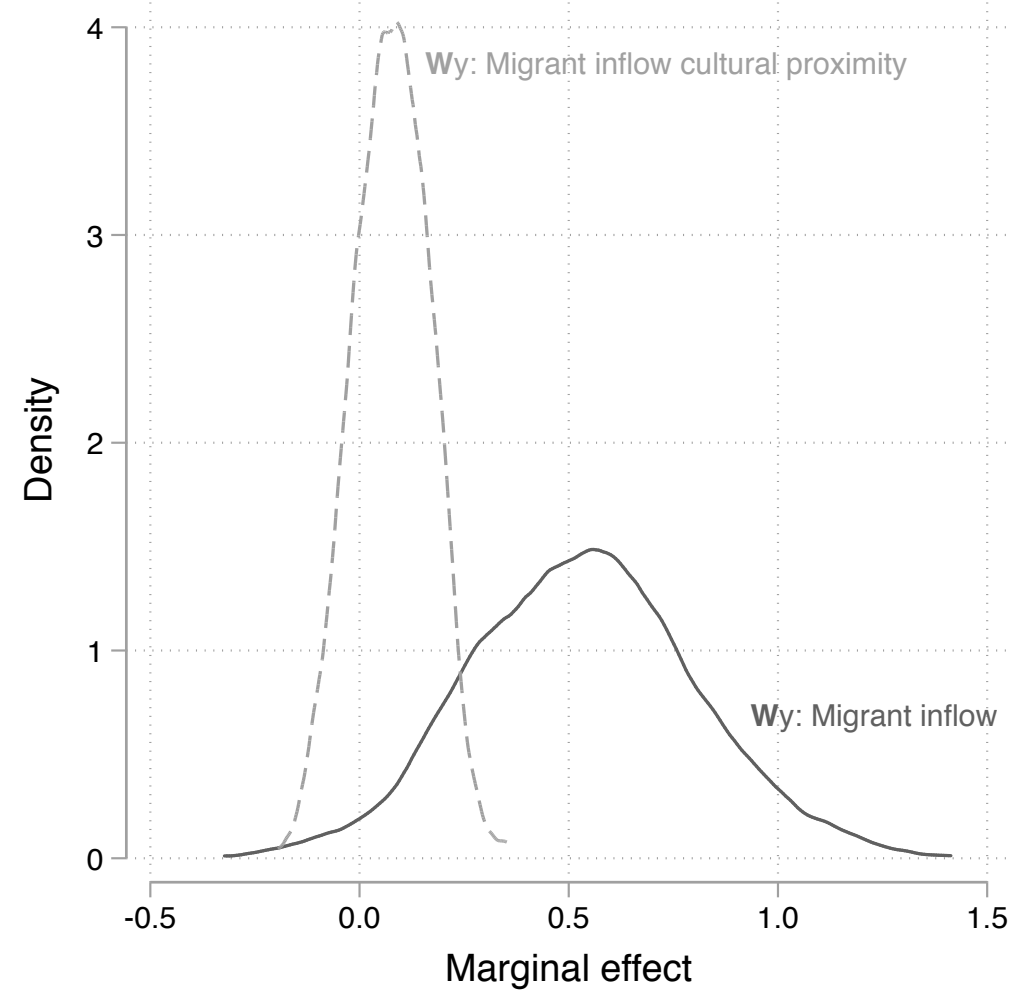

Graph shows simulated marginal effects differences of $\boldsymbol{W} y$ : Migrant inflow and $\boldsymbol{W} y$ : Migrant inflow cultural proximity, while holding all other covariates constant at their respective median.

In light of our hypothesis, we do not suggest that the cultural-proximity spatial lag should be negatively signed and/or significant, but that it should weaken and, thus, render insignificant the original spatial variable. As Model 2 shows, the spatial lag incorporating cultural closeness is now statistically insignificant, providing little evidence for a strong - or any - influence stemming from migration populations on terrorism diffusion when directly modelling that migrants come from culturally close countries. Changing model specifications by adding control variables, altering the way we calculate the standard errors, or considering refugee populations 
does not affect this finding qualitatively: as the Online appendix demonstrates, $\boldsymbol{W y}$ : Migrant inflow cultural proximity remains statistically insignificant even then. The conclusion holds when examining the simulated marginal effects following King et al. (2000) in Figure 1: while the marginal-effect estimates of $\boldsymbol{W y}$ : Migrant inflow center around 0.5 with only a small portion of the 1,000 simulated coefficients being 0 or negative (less than 2.3 percent of the simulated marginal effects), the simulated estimates of Wy: Migrant inflow cultural proximity converge toward 0 . Hence, we are unable to identify a statistically significant effect once we incorporate migrants' cultural proximity to their host society: cultural closeness does indeed dampen the diffusion of terrorism via migration flows. Interestingly, the substantive finding of migration being a vehicle for terrorism to diffuse across countries is unaltered for $\boldsymbol{W y}$ : Migrant inflow cultural distance. Substantively, Model 3 and 4 emphasize that a one-unit increase in $\boldsymbol{W} y$ : Migrant inflow cultural distance is associated with an increase in terrorist events by about 1.26. These results, in sum, emphasize in line with our theoretical expectations that more cultural proximity can address, contain, and indeed be a barrier to the diffusion of terrorism via migration. In other words, cultural proximity can dampen the diffusion effect of migration, while cultural distance does not.

This conclusion is based on statistical significance, but statistical significance may be a poor criterion for policy prescriptions (Ward et al., 2010). In their words, 'a variable that might at first be thought to represent an important conceptual breakthrough in our understanding of conflicts, owing to its statistical significance, often only leads to a very modest improvement in our ability to predict' outcomes (Ward et al. 2010, 365). Put differently, next to statistical significance, predictive power is an important factor to consider and out-of-sample heuristics must not be ignored for deciding whether the inclusion of a variable contributes to our understanding of, in our case, terrorism diffusion or not. This implies that we should be able to demonstrate not only that $\boldsymbol{W} y$ : Migrant inflow cultural proximity exerts an effect that is indistinguishable from 0 , but also that the inclusion of this variable leads to predictive gains that help us to generalize the effect of cultural proximity to out-of-sample contexts. Hence, not only should $\boldsymbol{W y}$ : Migrant inflow cultural proximity render insignificant the original spatial variable, but also the underlying model should perform better from a prediction point of view than the original setup when adding the information on cultural proximity. We thus conducted a 4-fold cross-validation quasi-experimental exercise, which we repeated 10 times for Models 1, 2, and 4 above and an additional model that is similar to the estimations in Table III, but we omit any of the spatial lags.

To this end, as an initial step, we randomly divided our sample into four segments of about the same size. We then used three random segments to estimate the parameters, while the fourth segment was retained for assessing the predictive power of either of the four models on the pooled subsets. We provide two goodnessof-fit measures in this out-of-sample setup. First, Theil's U is the square root of the ratio between the sum of squared prediction errors of a model and the sum of squared prediction errors of a naïve model, i.e. a 'no-change prediction' where the level of terrorism in $t-1$ fully corresponds to the level in $t$. If Theil's U is 
larger than 1, the model performs worse than the naïve model; values of Theil's U smaller than 1 indicate that the 'theoretically informed model' performs better than the naïve specification. Second, the mean squared prediction error (MSPE) pertains to the expected value of the squared difference between the observed values of the outcome variable and the predicted ones.

Table IV. 4-fold cross-validation

\begin{tabular}{lcccc}
\hline & Constrained model & Model 1 & Model 2 & Model 4 \\
\hline 1 & 0.823 & 0.801 & 0.814 & 0.803 \\
2 & $(0.462)$ & $(0.438)$ & $(0.451)$ & $(0.439)$ \\
& 0.820 & 0.823 & 0.806 & 0.818 \\
3 & $(0.458)$ & $(0.461)$ & $(0.444)$ & $(0.456)$ \\
& 0.828 & 0.828 & 0.815 & 0.817 \\
4 & $(0.468)$ & $(0.467)$ & $(0.453)$ & $(0.455)$ \\
& 0.821 & 0.813 & 0.819 & 0.817 \\
5 & $(0.459)$ & $(0.450)$ & $(0.457)$ & $(0.455)$ \\
& 0.824 & 0.817 & 0.816 & 0.818 \\
6 & $(0.463)$ & $(0.465)$ & $(0.454)$ & $(0.456)$ \\
& 0.816 & 0.806 & 0.813 & 0.807 \\
7 & $(0.454)$ & $(0.443)$ & $(0.451)$ & $(0.445)$ \\
& 0.821 & 0.828 & 0.802 & 0.816 \\
8 & $(0.459)$ & $(0.468)$ & $(0.438)$ & $(0.455)$ \\
& 0.802 & 0.812 & 0.820 & 0.815 \\
9 & $(0.438)$ & $(0.450)$ & $(0.459)$ & $(0.452)$ \\
& 0.815 & 0.828 & 0.818 & 0.813 \\
10 & $(0.453)$ & $(0.467)$ & $(0.456)$ & $(0.451)$ \\
& 0.830 & 0.826 & 0.818 & 0.817 \\
\hline \multirow{2}{*}{ Mean Value } & $(0.470)$ & $(0.465)$ & $(0.456)$ & $(0.455)$ \\
& 0.820 & 0.818 & 0.814 & 0.814 \\
\hline
\end{tabular}

Table entries are Theil's U values with MSPEs in parentheses.

We calculated both measures for Models 1, 2, and 4 as well as a constrained model that does not include any of the spatial lags. As indicated above, we repeated the cross-validation 10 times and, thus, obtain for each model 10 different values for Theil's U and the MSPE, respectively. We calculated the average values for both model-fit statistics to arrive at global values. The results are summarized in Table IV. For the constrained model, the average Theil's U across all 10 iterations of the cross-validation is 0.820 , while the corresponding MSPE stands at 0.458. Interestingly, both the corresponding average Theil's U and the MSPE values are lower for Models 1, 2, and 4. As a result, the predictive power of our core variables of interest is established as the prediction error tends to increase when omitting $\boldsymbol{W}$ : Migrant inflow, Wy: Migrant inflow cultural proximity, or Wy: Migrant inflow cultural distance.

In terms of control variables, our results are consistent with recent studies on the economic, political and social causes of terrorism (e.g. Wilson \& Piazza, 2013, Gaibulloev \& Sandler, 2018). We find that whereas larger countries attract more terrorist attacks, and thus Population (ln) is positively and significantly correlated with the incidence of terrorism, higher income is associated to a lower degree of terrorism, as GDP per capita (ln) is negatively signed (e.g. Young \& Findley, 2011). Similarly, and consistent with earlier studies, we find that the lagged dependent variable is positive and significant; in other words, terrorism 
displays temporal dependencies and a higher number of terrorist attacks in the previous year is correlated with more terrorism in the current period. The Democracy variable is statistically insignificant as is the alliance item, which is expected given our focus on OECD host countries. Finally, migration policies or the ('raw') migration population in the host country do not seem to crucially shape the level of terrorism. While omitting these variables from the models does not alter our results for $\boldsymbol{W} y$ : Migrant inflow cultural proximity and $\boldsymbol{W} y$ : Migrant inflow cultural distance, the insignificance of their coefficient estimates not only highlights yet again that migrants are not to blame for an increased risk of terrorism, but also that more restrictive national migration policies per se are unlikely to be all-encompassing instrument against terrorism.

In the Online appendix, we assess the robustness of our results along various avenues. First, we consider genetic distance in lieu of cultural distance. Second, we include additional variables to our estimations. Third, we run a series of models with bootstrapped standard errors. Fourth, we check whether the effect of democracy is non-linear. Fifth, although our theoretical focus is on the longer time horizon of migrants as opposed to refugees, we control for refugee inflows. Sixth, we drop all country-years based on interpolated migration data and distinguish between domestic and transnational terrorism $[18$ Finally, we examine shortterm migration influx, employ a different estimator, and compare explanatory variables across culturally-close and distant dyads.

\section{Conclusion}

A recent strand of academic research finds that terrorism at home can be influenced by terrorism abroad, and that population movements may facilitate this transnational diffusion of terrorism (Bove \& Böhmelt, 2016). One central argument of these works suggests that strong social bonds facilitate the establishment of 'terror networks' and a pre-established social framework is a key requirement for terror organizations radicalizing and recruiting individuals (Sageman, 2004, 2011). As migration flows comprise social ties and linkages, terrorist groups may exploit those networks of migrant communities for radicalization, as a recruitment pool, and to obtain indirect support through the exchange of ideas, resources, or knowledge.

Yet, cultural proximity between countries may shape individual interactions in diverse ways - and, as we contend, this has implications for terrorist organizations' recruitment possibilities as well as individuals' motives to directly or indirectly engage in terrorism. Migrants from culturally-close societies may have fewer difficulties integrating into host societies. In turn, social cohesion within societies evolves more easily with migrant communities from culturally closer places, which makes it more difficult for terrorist organization to radicalize and recruit followers. Combining this mechanism with the arguments about terrorism diffusion via migration flows led to the theoretical expectation that cultural proximity can contain, and act as a barrier to, such terrorism diffusion. In fact, we find little evidence for migrants being an instrument for the transnational

\footnotetext{
${ }^{18}$ The results across the two types of terrorism differ. Given that there are different causes, consequences, and policy implications for domestic and transnational terrorism, we discuss this finding in detail in the Online appendix.
} 
diffusion when accounting for and directly incorporating information on cultural closeness.

We build on existing arguments on how terrorism may diffuse via migration inflows, but we do not isolate the role of each mechanism that might drive this effect. There is a range of means of direct and indirect support that terrorist groups can obtain from marginalized immigrants, but the main obstacle for investigating them separately is the lack of comprehensive fine-grained data at the level of individuals or organizations. Future work should further disaggregate individuals and organizations as spatial units, and include information about their activities and positions in terrorist organizations, organizations' links across countries, and, most importantly, the possible role played by immigrants within these groups. In addition, our data do not allow determining whether immigrants are the perpetrators or victims of terrorist violence. There is ample evidence suggesting that foreign-born individuals are vulnerable to the violation of their rights and are too often the targets of violent persecution from hostile local populations (Savun \& Gineste, 2019, Böhmelt et al. 2019). Within the broader micro-turn in the study of immigration, recent scholarship has begun to compile new data on refugees' involvement in acts of physical violence in their host state, either as the victims or perpetrators of violence (see, e.g. Gineste \& Savun, 2019). Similar coding efforts with detailed information on the nationality and identity of victims and perpetrators of terrorism will allow scholars to assess under which conditions immigrants are targeted by terrorist violence, when and how they offer direct or indirect material support, and when they are exploited as a vehicle for such episodes of violence.

\section{References}

Adamson, Fiona (2006) Crossing borders: International migration and national security. International Security 31(1): 165-199.

Alarian, Hannah \& Sara Goodman (2017) Dual citizenship allowance and migration flow: An origin story. Comparative Political Studies 50(1): 133-167.

Alesina, Alberto \& Eliana Ferrara (2005) Ethnic diversity and economic performance. Journal of Economic Literature 43(3): 762-800.

Allport, Gordon W (1954) The nature of prejudice. Boston, MA: Addison-Wesley.

Angelini, Viola; Laura Casi \& Luca Corazzini (2015) Life satisfaction of immigrants: Does cultural assimilation matter? Journal of Population Economics 28(3): 817-844.

Bakaki, Zorzeta; Tobias Böhmelt \& Vincenzo Bove (2016) Barriers to coordination? Examining the impact of culture on international mediation occurrence and effectiveness. Political Studies 64(3): 492-512.

Blomberg, Brock \& Gregory Hess (2008) The Lexus and the olive branch: Globalization, democratization, and terrorism. In: Philip Keefer \& Normal Loayza (eds) Terrorism, economic development, and political openness. Cambridge: Cambridge University Press, 116-147. 
Böhmelt, Tobias \& Vincenzo Bove (forthcoming) How migration policies moderate the diffusion of terrorism. European Journal of Political Research. DOI: https://doi.org/10.1111/1475-6765.12339.

Böhmelt, Tobias; Vincenzo Bove \& Kristian Gleditsch (2019) Blame the victims? refugees, state capacity, and non-state actor violence. Journal of Peace Research 56(1): 73-87.

Bove, Vincenzo \& Tobias Böhmelt (2016) Does immigration induce terrorism? Journal of Politics 78(2): $572-588$.

Bove, Vincenzo \& Tobias Böhmelt (2019) International migration and military intervention in civil war. Political Science Research and Methods 7(2): 271-287.

Braithwaite, Alex \& Tiffany Chu (2018) Civil conflicts abroad, foreign fighters, and terrorism at home. Journal of Conflict Resolution 62(8): 1636-1660.

Braithwaite, Alex \& Quan Li (2007) Transnational terrorism hot spots: Identification and impact evaluation. Conflict Management and Peace Science 24(4): 281-296.

Breunig, Christian; Xun Cao \& Adam Luedtke (2012) Global migration and political regime type: A democratic disadvantage. British Journal of Political Science 42(4): 825-854.

Buhaug, Halvard \& Kristian Skrede Gleditsch (2008) Contagion or confusion? why conflicts cluster in space. International Studies Quarterly 52(2): 215-233.

Carnevale, Peter \& Dong-Won Choi (2000) Culture in the mediation of international disputes. International Journal of Psychology 35(2): 105-110.

Choi, Seung-Whan \& Idean Salehyan (2013) No good deed goes unpunished: Refugees, humanitarian aid, and terrorism. Conflict Management and Peace Science 30(1): 53-75.

Cohen, Raymond (1996) Cultural aspects of international mediation. In: Jacob Bercovitch (ed.) Resolving international conflicts: The theory and practice of international mediation. Boulder, CO: Lynne Rienner , 107-128.

De Wit, Thom \& Ruud Koopmans (2005) The integration of ethnic minorities into political culture: The Netherlands, Germany, and Great Britain compared. Acta Politica 40(1): 50-73.

Doosje, Bertjan; Annemarie Loseman \& Kees Bos (2013) Determinants of radicalization of Islamic youth in the Netherlands: Personal uncertainty, perceived injustice, and perceived group threat. Journal of Social Issues 69(3): 586-604.

Dowty, Alan \& Gil Loescher (1996) Refugee flows as grounds for international action. International Security 21(1): $43-71$. 
Dreher, Axel; Martin Gassebner \& Paul Schaudt (2017) The effect of migration on terror: Made at home or imported from abroad? CESifo Working Paper (6441).

Dustmann, Christian \& Tommaso Frattini (2014) The fiscal effects of immigration to the UK. Economic Journal 124(580): F593-F643.

Enders, Walter; Todd Sandler \& Khusrav Gaibulloev (2011) Domestic versus transnational terrorism: Data, decomposition, and dynamics. Journal of Peace Research 48(3): 319-337.

Findley, Michael; James Piazza \& Joseph Young (2012) Games rivals play: Terrorism in international rivalries. Journal of Politics 74(1): 235-248.

Franzese, Robert \& Jude Hays (2007) Spatial econometric models of cross-sectional interdependence in political science panel and time-series-cross-section data. Political Analysis 15(2): 140-164.

Franzese, Robert \& Jude Hays (2008) Interdependence in comparative politics: Substance, theory, empirics, substance. Comparative Political Studies 41(4/5): 742-780.

Gaibulloev, Khusrav; James Piazza \& Todd Sandler (2017) Regime types and terrorism. International Organization 71(3): 491-522.

Gaibulloev, Khusrav \& Todd Sandler (2018) What we have learned about terrorism since 9/11. Journal of Economic Literature 57(2): 275-328.

Ghosn, Faten; Alex Braithwaite \& Tiffany S Chu (2019) Violence, displacement, contact, and attitudes toward hosting refugees. Journal of Peace Research 56(1): 118-133.

Gibler, Douglas (2008) International Military Alliances, 1648-2008. Washington, DC: CQ.

Gineste, Christian \& Burcu Savun (2019) Introducing POSVAR: A dataset on refugee-related violence. Journal of Peace Research 56(1): 134-145.

Gokmen, Gunes (2017) Clash of civilizations and the impact of cultural differences on trade. Journal of Development Economics 127(1): 449-458.

Greenhill, Kelly (2010) Weapons of Mass Migration: Forced Displacement, Coercion, and Foreign Policy. Ithaca, NY: Cornell University Press.

Guiso, Luigi; Paola Sapienza \& Luigi Zingales (2006) Does culture affect economic outcomes? Journal of Economic Perspectives 20(2): 23-48.

Helbling, Marc; Liv Bjerre; Friederike Römer \& Malisa Zobel (2017) Measuring immigration policies: The IMPIC database. European Political Science 16(1): 79-98. 
Helbling, Marc \& David Leblang (2019) Controlling immigration? How regulations affect migration flows. European Journal of Political Research 58(1): 248-269.

Hogg, Michael (2011) Uncertainty-identity theory. In: Paul A M Van Lange, Anrie W Kruglanski \& E Tory Higgins (eds) Handbook of theories of social psychology. Thousand Oaks, CA: SAGE: 62-80.

Isphording, Ingo (2014) Disadvantages of linguistic origin? Evidence from immigrant literacy scores. Economics Letters 123(2): 236-239.

Kandogan, Yener (2012) An improvement to Kogut and Singh measure of cultural distance considering the relationship among different dimensions of culture. Research in International Business and Finance 26(2): 196-203.

King, Gary; Michael Tomz \& Jason Wittenberg (2000) Making the most of statistical analyses: Improving interpretation and presentation. American Journal of Political Science 44(2): 347-361.

Kogut, Bruce \& Harbir Singh (1988) The effect of national culture on the choice of entry mode. Journal of International Business Studies 19(3): 411-432.

Krieger, Tim \& Daniel Meierrieks (2011) What causes terrorism? Public Choice 147(1): 3-27.

Kubrin, Charis; John Hipp \& Young-An Kim (2018) Different than the sum of its parts: Examining the unique impacts of immigrant groups on neighborhood crime rates. Journal of Quantitative Criminology 34(1): $1-36$.

Li, Quan (2005) Does democracy promote or reduce transnational terrorist incidents? Journal of Conflict Resolution 49(2): 278-297.

Li, Quan \& Drew Schaub (2004) Economic globalization and transnational terrorist incidents: A pooled time series cross-sectional analysis. Journal of Conflict Resolution 48(2): 230-258.

Lischer, Sarah (2015) Dangerous sanctuaries: Refugee camps, civil war, and the dilemmas of humanitarian aid. Ithaca, NY: Cornell University Press.

Lyons-Padilla, Sarah; Michele J Gelfand; Hedieh Mirahmadi; Mehreen Farooq \& Marieke van Egmond (2015) Belonging nowhere: Marginalization \& radicalization risk among Muslim immigrants. Behavioral Science E Policy 1(2): 1-12.

Mahfud, Yara; Constantina Badea \& Ahogni Ngbala (2015) Cultural distance and prejudice against immigrants in France: The role of integration models. Revue Internationale de Psychologie Sociale 28(2): $53-79$ 
Mahfud, Yara; Constantina Badea; Maykel Verkuyten \& Kate Reynolds (2018) Multiculturalism and attitudes toward immigrants: The impact of perceived cultural distance. Journal of Cross-Cultural Psychology 49(6): 945-958.

Marshall, Monty \& Keith Jaggers (2015) Polity IV Project: Political regime characteristics and transitions, 1800-2014. Users' Manual. College Park, MD: University of Maryland.

Maxwell, Rahsaan (2010) Evaluating migrant integration: Political attitudes across generations in Europe. International Migration Review 44(1): 25-52.

Nemeth, Stephen; Jacob Mauslein \& Craig Stapley (2014) The primacy of the local: Identifying terrorist hot spots using geographic information systems. Journal of Politics 76(2): 304-317.

Neumayer, Eric \& Thomas Plümper (2010) Galton's problem and contagion in international terrorism along civilizational lines. Conflict Management and Peace Science 27(4): 308-325.

Ousey, Graham \& Charis Kubrin (2018) Immigration and crime: Assessing a contentious issue. Annual Review of Criminology 1(1): 63-84.

Özden, Çağlar; Christopher Parsons, Maurice Schiff \& Terrie Walmsley (2011) Where on earth is everybody? The evolution of global bilateral migration 1960-2000. World Bank Economic Review 25(1): 12-56.

Piazza, James (2006) Rooted in poverty? Terrorism, poor economic development, and social cleavages. Terrorism and Political Violence 18(1): 159-177.

Plümper, Thomas \& Eric Neumayer (2010) Model specification in the analysis of spatial dependence. European Journal of Political Research 49(3): 418-442.

Plümper, Thomas; Vera Troeger \& Philip Manow (2005) Panel data analysis in comparative politics. European Journal of Political Research 44(2): 327-354.

Rahimi, Sadeq \& Raissa Graumans (2015) Reconsidering the relationship between integration and radicalization. Journal for Deradicalization 5(1): 28-62.

Sageman, Marc (2004) Understanding terror networks. Philadelphia, PA: University of Pennsylvania Press.

Sageman, Marc (2011) Leaderless Jihad: Terror networks in the twenty-first century. Philadelphia, PA: University of Pennsylvania Press.

Salehyan, Idean (2008) The externalities of civil strife: Refugees as a source of international conflict. American Journal of Political Science 52(4): 787-801.

Salehyan, Idean \& Kristian Skrede Gleditsch (2006) Refugees and the spread of civil war. International Organization 60(2): 335-366. 
Savun, Burcu \& Christian Gineste (2019) From protection to persecution: Threat environment and refugee scapegoating. Journal of Peace Research 56(1): 88-102.

Schmid, Alex (2016) Links between terrorism and migration. International Centre For Counter Terrorism (ICCT) ICCT Research Paper.

Skeldon, Ronald (2008) International migration as a tool in development policy: A passing phase? Population and Development Review 34(1): 1-18.

Spolaore, Enrico \& Romain Wacziarg (2016) War and relatedness. Review of Economics and Statistics 98(5): 925-939.

UN DESA (2016) International migration report. New York: UN Department of Economic and Social Affairs, Population Division.

Velasco González, Karina; Maykel Verkuyten; Jeroen Weesie \& Edwin Poppe (2008) Prejudice towards Muslims in the Netherlands: Testing integrated threat theory. British Journal of Social Psychology 47(4): $667-685$.

Vidino, Lorenzo; Francesco Marone \& Eva Entenmann (2017) Fear thy neighbor: Radicalization and Jihadist attacks in the West. Milano: Ledizioni Ledi.

Vigdor, Jacob (2015) The civic and cultural assimilation of immigrants to the United States. In: Benjamin Powell (ed.) The Economics of Immigration: Market-Based Approaches, Social Science, and Public Policy. Oxford: Oxford Scholarship Online.

Ward, Michael D; Brian Greenhill \& Kristin Bakke (2010) The perils of policy by p-value: Predicting civil conflicts. Journal of Peace Research 47(4): 363-375.

Weiner, Myron (1992) Security, stability, and international migration. International Security 17(3): 91-126.

Wenger, Andreas \& Victor Mauer (2009) The radicalization of diasporas and terrorism. Zürich: Center for Security Studies.

Wilson, Matthew \& James Piazza (2013) Autocracies and terrorism: Conditioning effects of authoritarian regime type on terrorist attacks. American Journal of Political Science 57(4): 941-955.

Young, Joseph \& Michael Findley (2011) Promise and pitfalls of terrorism research. International Studies Review 13(3): 411-431.

Zimmermann, Doron \& William Rosenau (2009) Introduction. In: Doron Zimmermann \& William Rosenau (eds.) The radicalization of diasporas and terrorism, Volume 80. Zurich: ETH. 


\section{Does cultural proximity contain terrorism diffusion? - Online appendix}

In this appendix, we provide additional information on the construction of the spatial lags, as well as further information on the data for cultural proximity and distance. We have also performed additional tests to assess the robustness of our findings. All these additional checks can be replicated with the data and model instructions. They further increase the confidence in our finding that cultural proximity can contain, and act as a barrier to, terrorism diffusion via migration and include:

- We consider genetic distance instead of cultural distance.

- Additional control variables that capture alternative determinants of terrorism and may correlate with the factors driving migration.

- We estimate a series of models with bootstrapped standard errors.

- We present models that examine curvilinear effects of democracy.

- Models when controlling for refugees.

- We drop all country-years based on interpolated migration data and re-estimate the core models using non-interpolated data only.

- We distinguish between domestic and transnational forms of terrorism.

- Instead of the stock of migrants for the spatial lags, we considered yearly changes in the migrant population.

- We re-estimated the core models using the number of terrorist attacks as the outcome variable with negative binomial regression as an alternative estimator.

- We assessed the differences in core explanatory variables across culturally-close and distant dyads.

\section{A1. Additional information on the construction of the spatial lags}

The core of our methodological approach and, hence, the empirical analysis is a set of three spatial lags. All spatial items are based on a matrix that links countries via migrant populations. Given a monadic, country-year unit of analysis, we created a data set comprising OECD countries only in 1980-2010. Data limitations of our explanatory variables, primarily the immigration-policy variable and GDP per capita (ln), eventually lead to the 911 observations. The matrix we use to capture country links via (1) migration and (2) migration as well as cultural proximity is not based on a $911 \times 911$ matrix, though, as we would then only capture intra-OECD migration and cultural links. Instead, we embedded the 911 OECD observations from our 'core' monadic data set into a data file comprising all other countries in 1980-2010, eventually ending up with 6,099 cases. We 
used this broader, still monadic data set to first create a directed-dyads data file and, second, a 6,099 × 6,099 matrix comprising the links among all countries across all years between 1980 and 2010. After we compiled all necessary matrices, we created the spatial lags in the larger monadic data set comprising 6,099 observations so to match the dimension of the matrix. Then, we merged all spatial variables into the 911-cases data file. The 'detour' via the 6,099-cases data file is necessary as - despite our focus on OECD countries - we want to include the influence of terrorism, migration, and cultural proximity from outside this group.

\section{A2. Additional information on the operationalization of cultural dis-}

\section{tance}

We measure cultural proximity between two countries $i, j$ in the matrices via the inverse of the culturaldifferences information in Kandogan (2012), which is a revised variable of the standardized measure of cultural distance introduced in Kogut \& Singh (1988). The underlying foundation for this understanding of cultural differences is similar to the definitions introduced in Hofstede (1980, p.13) who approaches culture as 'the collective programming of the mind, which distinguishes the members of one human group from another.' This treatment translates into country classifications along four core anthropological subjects that cultures may evaluate differently and affect societal norms, customs, or beliefs: the ways of dealing with inequality, the ways of dealing with uncertainty, the relationship of an individual with her primary group, and gender implications. Derived from these features, Kandogan (2012) developed a composite index based on the deviation from each of the four dimensions of national culture in Hofstede (1980).

Note that although not all immigrants are culturally different from the native population of their destination countries, cultural heterogeneity in modern society is largely driven by migration patterns (see, e.g., Putnam, 2007). Thus, immigration could affect our markers of cultural proximity if the two were considered in and are based on the same period. Yet, while our migration data cover the period 1980-2010, the measure of cultural distance largely pre-dates contemporary migration flows. That is, the measure of cultural proximity from Kandogan (2012) is a composite index based on the deviation from each of the four dimensions of national culture in Hofstede (1980). Hofstede created ordinal scales for countries for each of these dimensions using standardized factor analysis of questionnaires administered between 1968 and 1972. Although immigration to OECD countries has a long history, according to our data set as well as reports by, e.g., OECD-UNDESA's World Migration in Figures, the number of international migrants in the global North has significantly increased by $65 \%$ only as of the 1990s. Moreover, during the period 2000-2010 alone did the global migrant stock grow twice as fast than during the previous decade. 


\section{A3. Alternative approach to capture cultural distance: Genetic dis-}

\section{tance}

We replaced cultural distance by genetic distance, which captures differences in allele frequencies across a range of neutral genes. There are several versions of this variable (see Spolaore \& Wacziarg, 2009, Cavalli-Sforza et al. 1995). We use the item from Spolaore \& Wacziarg (2009), called $F_{S T}$, which is a measure of distance to the most recent common ancestors of two populations, i.e., their degree of genealogical relatedness, or equivalently, the length of time since two populations split apart. $F_{S T}$ is constructed using information on 128 alleles related to 45 selectively neutral genes. It includes alleles coding for blood groups, immunoglobulin, hemoglobin, enzymes, and lymphocyte antigens (see Spolaore \& Wacziarg, 2009, Cavalli-Sforza et al. 1995) In In the words of Spolaore \& Wacziarg (2016, p.925), '[h] euristically, the concept [of genetic distance] is analogous to relatedness between individuals: two siblings are more closely related than two cousins because they share more recent common ancestors: their parents rather than their grandparents. Since many characteristics, including cultural traits and preferences, are transmitted across generations over the long run, genetic distance provides a comprehensive measure of distance in such traits across populations.'

Spolaore \& Wacziarg (2009) first took the data on 42 world populations for which Cavalli-Sforza et al. (1995) report all bilateral distances. As Spolaore \& Wacziarg (2009) note, the greatest genetic distance is between Mbuti Pygmies and Papua New Guineans, $\left(F_{S T}=0.4573\right)$, while the smallest is between Danish and English $\left(F_{S T}=0.0021\right)$. Figure A.1 in this appendix summarizes the distances among 42 human populations and how have they have split apart over time.

To create data at the country level, rather than the population level, Spolaore \& Wacziarg (2009) matched populations to countries using data on ethnic composition from Alesina et al. (2003). As different ethnic groups may be present in one country, Spolaore \& Wacziarg (2009) used the full list of 1,120 country-ethnic group categories where the group label was available. Consider, for example, Italy, 'where the ethnic groups labelled 'Italian' and 'Rhaetian' (a combined $95.4 \%$ of the population) were matched to the genetic category 'Italian,' whereas the 'Sardinian' ethnic group ( $2.7 \%$ of the population) was matched to the 'Sardinian' genetic group' (Spolaore \& Wacziarg, 2009, p.484). That said, $F_{S T}$ is based on dominant groups. As in Spolaore \& Wacziarg (2009, 2016), to better determine the expected genetic distance between two randomly selected individuals, we use data weighted by the share of population belonging to each distinct ancestral group in each country, rather than genetic distance based on dominant groups only. Assume that country 1 contains populations $i=1, \ldots, I$ and $s_{1 i}$ are their shares, whereas country 2 comprises populations $j=1, \ldots, J$ and $s_{2 j}$ are their shares. Assume that $d_{i j}$ is the genetic distance between populations $i$ and $j$. Then, the weighted $F_{S T}$ genetic distance between state 1 and state 2 is,

\footnotetext{
${ }^{1}$ Note that Cavalli-Sforza et al. (1995) sampled populations based on the year 1500, thus reducing the extent of measurement error.
} 
Figure I. Genetic distances among 42 populations

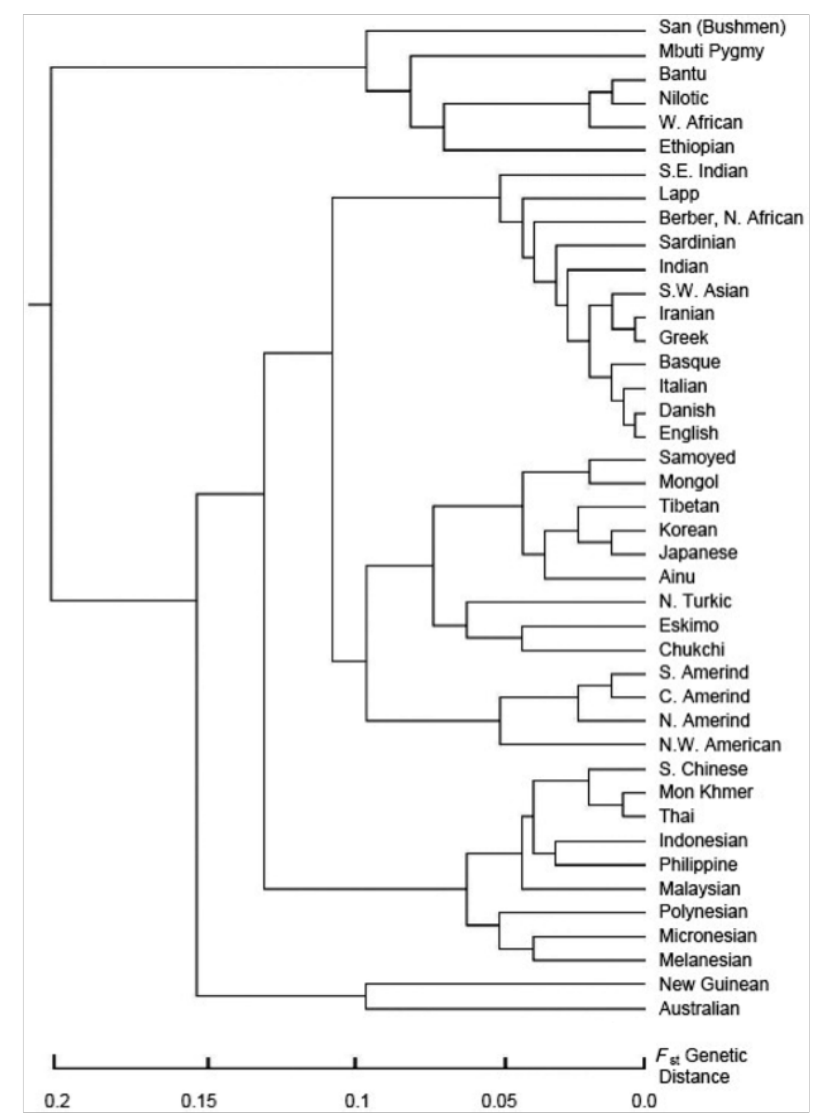

Note: Source is Cavalli-Sforza et al. 1995. Figure taken from Spolaore \& Wacziarg (2009 p.483).

$$
F_{S T}^{W}=\sum_{i=1}^{I} \sum_{j=1}^{J}\left(s_{1 i} \times s_{2 j} \times d_{i j}\right)
$$

where $s_{k i}$ is the share of the group $i$ in country $k$ and $d_{i j}$ is the genetic distance between $i$ and $j$. This can be interpreted as the expected genetic distance between two randomly selected individuals from 1 and 2 and takes into account the diversity within each society and their sub-populations. By measuring the time since two populations shared common ancestors, genetic distance provides an ideal summary of differences in slowly changing genealogically transmitted characteristics, including habits and customs (Spolaore \& Wacziarg, 2009 , p.523).

Similar to culture in the main text, we reversed the scale of the dyadic item so that higher values pertain to more genetic proximity between two states. We divided this information into four equally sized groups, with the two genetically closest groups receiving a value of 1 in the elements $w_{i, j}$. These entries are multiplied by the migrant population in country $i$ that has country $j$ as the state of origin in $t$ - 1 in order to capture migrant flows between $i$ and $j$, while the two countries are genetically close to each other. Spolaore \& Wacziarg (2016) demonstrate that genetic distance is correlated with a wide set of cultural differences. Hence, our analysis based on genetic distance is a robustness check for our cultural-distance estimations. As Table A.1 of this appendix summarizes, the migration-based spatial lag incorporating genetic proximity is statistically insignificant - similar to $\boldsymbol{W y}$ : Migrant inflow cultural proximity in the main text. 
Table I. Terrorism diffusion: The role of genetic proximity

\begin{tabular}{|c|c|}
\hline & Model A1 \\
\hline Lagged dependent variable & $\begin{array}{c}0.475^{* *} \\
(0.030)\end{array}$ \\
\hline Wy: Migrant inflow genetic proximity & $\begin{array}{c}0.290 \\
(0.203)\end{array}$ \\
\hline Alliance with US & $\begin{array}{c}0.163 \\
(0.151)\end{array}$ \\
\hline Democracy & $\begin{array}{c}0.001 \\
(0.012)\end{array}$ \\
\hline GDP per capita $(\ln )$ & $\begin{array}{r}-0.415^{\dagger} \\
(0.216)\end{array}$ \\
\hline Population (ln) & $\begin{array}{c}1.074^{*} \\
(0.504)\end{array}$ \\
\hline Total migration population & $\begin{array}{c}0.012 \\
(0.018)\end{array}$ \\
\hline Internal immigration policy restrictions & $\begin{array}{c}0.177 \\
(0.497)\end{array}$ \\
\hline Constant & $\begin{array}{r}-9.353 \\
(6.500)\end{array}$ \\
\hline Observations & 911 \\
\hline Country fixed effects & Yes \\
\hline Year fixed effects & Yes \\
\hline Prob. $>\mathrm{F}$ & 0.000 \\
\hline
\end{tabular}

\section{A4. Additional control variables}

For the models in the main text, we have included country fixed effects, year fixed effects, a lagged dependent variable, and a set of alternative predictors of terrorism as well as, potentially, migration flows. This way, we have sought to address the issue of common exposure in an efficient way. The substantive controls considered in the main text are based on a rather parsimonious approach, however. In the following, we re-estimate our main models after having added additional controls as suggested in Gaibulloev et al. (2017). First, Gaibulloev et al. (2017, p.15) recommend controlling for variables that capture a state's involvement in foreign policy. To this end, there are items on interventions and the involvement in international crises. Using data by Pickering \& Kisangani (2009), the intervention variable counts a country's number of military interventions in a given year. The crisis item is dichotomous as it captures state involvement in any international crisis in the last three years (coded as 1; 0 otherwise). We use the International Crisis Behavior project's data for this. Moreover, there is Regime age, which is taken from Marshall \& Jaggers (2015) and codes the age of the current regime (time elapsed since the current regime came to power). The higher the value of that item, the more stable the leader's regime.

Table A.2 in this appendix summarizes our findings when including these additional controls. Most importantly for our study, the main findings remain robust in that $\boldsymbol{W y}$ : Migrant inflow becomes statistically insignificant once we take cultural proximity (Model A3) into account. On the other hand, all of the newly added items are statistically insignificant at conventional levels. However, this may be driven by the fixed 
Table II. Terrorism diffusion: Additional controls

\begin{tabular}{|c|c|c|}
\hline & Model A2 & Model A3 \\
\hline Lagged dependent variable & $\begin{array}{c}0.457^{* *} \\
(0.033)\end{array}$ & $\begin{array}{c}0.456^{* *} \\
(0.033)\end{array}$ \\
\hline $\mathbf{W} y$ : Migrant inflow & $\begin{array}{c}0.608^{\dagger} \\
(0.314)\end{array}$ & \\
\hline Wy: Migrant inflow cultural proximity & & $\begin{array}{c}0.048 \\
(0.108)\end{array}$ \\
\hline Alliance with US & $\begin{array}{c}0.189 \\
(0.165)\end{array}$ & $\begin{array}{c}0.130 \\
(0.162)\end{array}$ \\
\hline Democracy & $\begin{array}{c}0.001 \\
(0.014)\end{array}$ & $\begin{array}{r}-0.003 \\
(0.014)\end{array}$ \\
\hline GDP per capita $(\ln )$ & $\begin{array}{c}-0.666^{* *} \\
(0.255)\end{array}$ & $\begin{array}{r}-0.565^{*} \\
(0.253)\end{array}$ \\
\hline Population (ln) & $\begin{array}{c}1.416^{*} \\
(0.633)\end{array}$ & $\begin{array}{r}1.035^{\dagger} \\
(0.601)\end{array}$ \\
\hline Total migration population & $\begin{array}{c}0.028 \\
(0.025)\end{array}$ & $\begin{array}{c}0.018 \\
(0.025)\end{array}$ \\
\hline Internal immigration policy restrictions & $\begin{array}{c}0.028 \\
(0.566)\end{array}$ & $\begin{array}{r}-0.115 \\
(0.567)\end{array}$ \\
\hline Military interventions & $\begin{array}{r}-0.090 \\
(0.060)\end{array}$ & $\begin{array}{r}-0.086 \\
(0.060)\end{array}$ \\
\hline Crisis experience & $\begin{array}{c}0.037 \\
(0.085)\end{array}$ & $\begin{array}{c}0.041 \\
(0.085)\end{array}$ \\
\hline Regime age & $\begin{array}{r}-0.003 \\
(0.006)\end{array}$ & $\begin{array}{r}-0.002 \\
(0.006)\end{array}$ \\
\hline Constant & $\begin{array}{r}-9.503 \\
(8.021)\end{array}$ & $\begin{array}{r}-5.458 \\
(7.748)\end{array}$ \\
\hline Observations & 783 & 783 \\
\hline Country fixed effects & Yes & Yes \\
\hline Year fixed effects & Yes & Yes \\
\hline Prob. $>\mathrm{F}$ & 0.000 & 0.000 \\
\hline
\end{tabular}

Standard errors in parentheses.

$\dagger \mathrm{p}<0.10, * \mathrm{p}<0.05, * * \mathrm{p}<0.01$ 
effects we include, which limit our ability to make inferences about time-invariant or slow-moving variables. Coefficients are then not identified or difficult to estimate with precision.

\section{A5. Bootstrapped standard errors}

The dependent variable changes over time as a function of both within-subject changes and the relative position of each country (due to the spatial lags). Given this interdependence of cases, the errors might not be independent and identically distributed. We thus considered bootstrapping the standard errors to address this. According to Guanet al. (2003, p.71), '[b]ootstrapping is a nonparametric approach for evaluating the distribution of a statistic based on random re-sampling.' The procedure is thus based on random sample draws (with replacement) repeatedly from the sample data. We opted for 1,000 draws per model estimation. Table A.3 in this appendix summarizes our findings for this robustness check: the coefficient estimates are identical to those presented in the main text and only the standard errors change. Interestingly, though, none of our substantive results is affected as Wy: Migrant inflow is significant in Model A4, but no longer in Model A5 when we incorporate the information on cultural proximity.

Table III. Terrorism diffusion: Bootstrapped standard errors

\begin{tabular}{lcc}
\hline & Model A4 & Model A5 \\
\hline Lagged dependent variable & $0.475^{* *}$ & $0.474^{* *}$ \\
& $(0.039)$ & $(0.039)$ \\
Wy: Migrant inflow & $0.529^{\dagger}$ & \\
& $(0.275)$ & \\
Wy: Migrant inflow cultural proximity & & 0.074 \\
& & $(0.093)$ \\
Alliance with US & 0.185 & 0.136 \\
& $(0.134)$ & $(0.137)$ \\
Democracy & 0.002 & -0.003 \\
& $(0.014)$ & $(0.014)$ \\
GDP per capita (ln) & $-0.439^{*}$ & $-0.372^{\dagger}$ \\
& $(0.216)$ & $(0.222)$ \\
Population (ln) & $1.213^{*}$ & $0.953^{\dagger}$ \\
Total migration population & $(0.485)$ & $(0.495)$ \\
& 0.012 & 0.006 \\
Internal immigration policy restrictions & $(0.020)$ & $(0.020)$ \\
& $(0.293$ & 0.222 \\
Constant & $-6.634)$ & $(0.486)$ \\
& $(4.637)$ & -4.558 \\
Observations & 911 & $(4.777)$ \\
Country fixed effects & Yes & 911 \\
Year fixed effects & Yes & Yes \\
Prob. $>$ F & 0.000 & 0.000 \\
\hline Boostrapped & & \\
& & \\
& &
\end{tabular}

Bootstrapped standard errors in parentheses.

$\dagger \mathrm{p}<0.10, * \mathrm{p}<0.05, * * \mathrm{p}<0.01$ 


\section{A6. Non-linear effect of Democracy}

There is little agreement as to how democracy affects terrorism. Advanced democracies, particularly those with an active or ambitious foreign-policy agenda, are often the target of transnational terrorism, although less-developed democracies with territorial conflicts and without institutional channels to express grievances against the state can also be prone to terrorism (Chenoweth, 2013). In addition, Gaibulloev et al. (2017) argue that the level of democracy exerts an impact on terrorism that follows an inverted-U shaped curve: the level of terrorism is rather low in strong autocracies and perfect democracies, but more directly pronounced in mixed regimes, i.e., anocracies. To examine this possibility, while checking the robustness of our core findings, we added a square term of Democracy to our models. The revised estimates are summarized in Table A.4 of this appendix.

Table IV. Terrorism diffusion: Non-linear effect of Democracy

\begin{tabular}{lcc}
\hline & Model A6 & Model A7 \\
\hline Lagged dependent variable & $0.475^{* *}$ & $0.474^{* *}$ \\
& $(0.030)$ & $(0.030)$ \\
Wy: Migrant inflow & $0.528^{\dagger}$ & \\
& $(0.271)$ & \\
Wy: Migrant inflow cultural proximity & & 0.074 \\
Alliance with US & 0.188 & $(0.093)$ \\
& $(0.152)$ & 0.139 \\
Democracy & -0.003 & $-0.150)$ \\
& $(0.015)$ & $(0.015)$ \\
Democracy & & 0.001 \\
& 0.001 & $(0.003)$ \\
GDP per capita (ln) & $(0.003)$ & $-0.368^{\dagger}$ \\
& $-0.435^{*}$ & $(0.215)$ \\
Population (ln) & $(0.214)$ & $0.955^{\dagger}$ \\
& $1.214^{*}$ & $(0.494)$ \\
Total migration population & $(0.514)$ & 0.008 \\
& 0.013 & $(0.018)$ \\
Internal immigration policy restrictions & $(0.018)$ & 0.250 \\
Constant & 0.320 & $(0.511)$ \\
& $-6.505)$ & -4.758 \\
Observations & $(4.646)$ & $(4.526)$ \\
Year fixed effects $>$ F & 911 & 911 \\
\hline Stob. & Yes & 0.000 \\
\hline
\end{tabular}

Standard errors in parentheses.

$\dagger \mathrm{p}<0.10, * \mathrm{p}<0.05, * * \mathrm{p}<0.01$

As we can see, our main finding remains robust and is not crucially affected by specifying a curvilinear effect for Democracy: Wy: Migrant inflow cultural proximity remains insignificant as expected, but we find little evidence for a non-linear relationship between Democracy and Terrorism (ln). Yet, given the rather homogeneous sample with an average polity score of 8.9 , this result is not surprising. 
Table V. Terrorism diffusion: Controlling for refugee populations

\begin{tabular}{lcc}
\hline & Model A8 & Model A9 \\
\hline Lagged dependent variable & $0.476^{* *}$ & $0.474^{* *}$ \\
Wy: Migrant inflow & $(0.030)$ & $(0.030)$ \\
& $0.531^{\dagger}$ & \\
Wy: Migrant inflow cultural proximity & $(0.271)$ & \\
& & 0.076 \\
Alliance with US & 0.184 & $(0.093)$ \\
& $(0.152)$ & 0.136 \\
Democracy & 0.001 & $-0.150)$ \\
& $(0.012)$ & $(0.011)$ \\
GDP per capita (ln) & $-0.436^{*}$ & $-0.371^{\dagger}$ \\
& $(0.214)$ & $(0.215)$ \\
Population (ln) & $1.192^{*}$ & $0.932^{\dagger}$ \\
Total migration population & $(0.518)$ & $(0.498)$ \\
& 0.012 & 0.007 \\
Total refugee population & $(0.018)$ & $(0.018)$ \\
Internal immigration policy restrictions & -0.083 & -0.087 \\
Constant & $(0.262)$ & $(0.262)$ \\
& 0.300 & 0.231 \\
Observations & $(0.503)$ & $(0.509)$ \\
Year fixed effects & $-11.072^{\dagger}$ & -7.462 \\
Prob. $>$ F & $(6.720)$ & $(6.439)$ \\
\hline
\end{tabular}

Standard errors in parentheses.

$\dagger \mathrm{p}<0.10, * \mathrm{p}<0.05, * * \mathrm{p}<0.01$ 


\section{A7. Controlling for refugee populations}

As indicated in the main text, our theoretical argument pertains to diaspora communities or people that are permanently settled in a country, while refugee flows are a temporary movement of individuals who have fled violence and now seek protection. We thus focus on the longer time horizon of migrants as opposed to refugees. Having said that, previous studies identified several different ways in which an increase in a state's refugee population might give rise to conflict and political violence (see, e.g., Dowty \& Loescher, 1996, Salehyan \& Gleditsch, 2006, Gleditsch, 2007, Milton et al., 2013, Benmelech \& Klor, 2016, Zhou \& Shaver, 2018). We therefore re-estimated our main models while including a variable that captures the refugee population in a given country-year (in millions) and is based on the UNHCR Population Statistics Reference Database. These data provide information on the number of different 'population types' and we concentrate on refugees, persons in refugee-like situations, and asylum seekers as the relevant population types to calculate the total number of these groups in a country-year. Internally displaced persons or returnees are excluded from our measure. We replaced any missing observations in their data by 0s. Table A.5 in this appendix presents our results: as demonstrated there, neither is Refugees associated with a statistically significant effect nor does our core finding differ in any way from what we discuss in the article.

Table VI. Terrorism diffusion: Non-interpolated data

\begin{tabular}{lc}
\hline & Model A10 \\
\hline Lagged dependent variable & $0.504^{* *}$ \\
Wy: Migrant inflow cultural proximity & $(0.106)$ \\
& -0.049 \\
Alliance with US & $(0.365)$ \\
& 0.548 \\
Democracy & $(0.471)$ \\
& 0.023 \\
GDP per capita $(\ln )$ & $(0.032)$ \\
& -0.259 \\
Population $($ ln) & $(0.720)$ \\
& $4.208^{* *}$ \\
Total migration population & $(1.534)$ \\
& -0.026 \\
Internal immigration policy restrictions & $(0.079)$ \\
& -1.362 \\
Constant & $(1.900)$ \\
& $-47.709^{*}$ \\
\hline Observations & $(20.445)$ \\
Country fixed effects & 89 \\
Year fixed effects & Yes \\
Prob. $>$ F & Yes \\
\hline$\dagger p<0.10, *$ p $<0.05, * *$ p $<0.01$ & 0.000 \\
Standard errors in parentheses & \\
&
\end{tabular}




\section{A8. Non-interpolated data}

As discussed in the main text, data on migrant populations are taken from the World Bank (Özden et al. 2011) and we rely on the number of people born in a country other than that in which they live. The estimates are derived from national census and population register records 2 Each census round was conducted during a 10-year window and we thus linearly interpolate all missing data between two consecutive rounds. However, migration patterns are a function of many complex socio-economic and political variables that do not necessarily move linearly. We thus re-estimated our core model that focuses on $\boldsymbol{W y}$ : Migrant inflow cultural proximity using country-years based on non-interpolated data only to see whether the insignificance of this spatial variable is driven by particularities of the larger sample.

The sample size drops to 89 observations, but our core finding remains robust as Table A.6 in this appendix demonstrates: $\boldsymbol{W} y$ : Migrant inflow cultural proximity remains statistically insignificant, which underlines that cultural closeness can act as a barrier to the diffusion of terrorism via migration.

\section{A9. Transnational vs. domestic terrorism diffusion}

We changed the specifications for the dependent variable and the spatial lags so that we separately study domestic terrorism and transnational attacks. Domestic terrorism pertains to those cases where the nationalities of the perpetrators and the victims are the same (Enders et al. 2011, p.321). Conversely, international or transnational terrorism is based on a comparison between the location of the attack and the nationality of the $\operatorname{target}(\mathrm{s}) / \operatorname{victim}(\mathrm{s})$. If a perpetrator group attacked a target of a different nationality, terrorism is not of a domestic, but a transnational dimension. Making the distinction between domestic and transnational terrorism affects the operationalization of the outcome variables, the temporally lagged dependent variables, and the spatial variables. Table A.7 in this appendix summarizes our findings.

Our results for domestic terrorism are similar to what we report in the main text: there is a positive and statistically significant effect of $\boldsymbol{W} y$ : Migrant inflow, but this item then becomes insignificant when considering cultural proximity. For transnational terrorism, however, $\boldsymbol{W y}$ : Migrant inflow cultural proximity is statistically significant and positively signed. There are several reasons for why the findings are inconclusive for transnational, but not for domestic terrorism. First, as discussed in Bove \& Böhmelt (2016), migration flows may also be linked to domestic forms of terrorism, not necessarily or exclusively transnational terrorism. For example, migration could increase the exposure of domestic groups to prospects for mobilization by the same or a different group in the country of migration origin, thus making emulation more likely to emerge. Also, migrants from a country prone to terrorist attacks could more easily be willing and able to support domestic terrorist groups (see Adamson, 2006). Large migration flows facilitate the exchange of ideas, and terrorist groups in the host country often lack the relevant experience to organize terrorist activities, especially when they share the same goals and aspiration of the home-grown terrorists.

\footnotetext{
${ }^{2}$ Available online at: http://www.un.org/en/development/desa/population/migration/data/index.shtml
} 
Table VII. Terrorism diffusion: Transnational vs. domestic terrorism

\begin{tabular}{lcccc}
\hline & $\begin{array}{c}\text { Model A11 } \\
\text { Transnational }\end{array}$ & $\begin{array}{c}\text { Model A12 } \\
\text { Transnational }\end{array}$ & $\begin{array}{c}\text { Model A13 } \\
\text { Domestic }\end{array}$ & $\begin{array}{c}\text { Model A14 } \\
\text { Domestic }\end{array}$ \\
\hline Lagged dependent variable & $0.423^{* *}$ & $0.422^{* *}$ & $0.475^{* *}$ & $0.473^{* *}$ \\
& $(0.032)$ & $(0.031)$ & $(0.039)$ & $(0.040)$ \\
Wy: Migrant inflow & -0.194 & & $0.695^{*}$ & \\
& $(0.438)$ & & $(0.285)$ & \\
Wy: Migrant inflow cultural proximity & & & 0.126 \\
& & $0.227^{\dagger}$ & & $(0.087)$ \\
Alliance with US & 0.147 & $(0.117)$ & 0.198 & 0.142 \\
& $(0.137)$ & 0.170 & $(0.132)$ & $(0.133)$ \\
Democracy & 0.002 & $0.135)$ & -0.001 & -0.005 \\
& $(0.011)$ & $(0.010)$ & $(0.013)$ & $(0.014)$ \\
GDP per capita (ln) & -0.153 & -0.225 & $-0.493^{*}$ & $-0.399^{\dagger}$ \\
& $(0.187)$ & $(0.190)$ & $(0.209)$ & $(0.207)$ \\
Population (ln) & 0.720 & $0.872^{\dagger}$ & $1.024^{*}$ & 0.775 \\
& $(0.476)$ & $(0.447)$ & $(0.521)$ & $(0.534)$ \\
Total migration population & 0.000 & -0.002 & 0.014 & 0.008 \\
& $(0.016)$ & $(0.016)$ & $(0.020)$ & $(0.020)$ \\
Internal immigration policy restrictions & 0.261 & 0.378 & 0.370 & 0.290 \\
& $(0.453)$ & $(0.454)$ & $(0.425)$ & $(0.426)$ \\
Constant & -7.221 & -8.993 & -8.667 & -5.429 \\
& $(6.319)$ & $(5.791)$ & $(6.718)$ & $(6.931)$ \\
\hline Observations & 911 & 911 & 911 & 911 \\
Country fixed effects & Yes & Yes & Yes & Yes \\
Year fixed effects & Yes & Yes & Yes & Yes \\
Prob. $>$ F & 0.000 & 0.000 & 0.000 & 0.000 \\
\hline
\end{tabular}

$\dagger \mathrm{p}<0.10, * \mathrm{p}<0.05, * * \mathrm{p}<0.01$

Standard errors in parentheses

Second, anti-migration groups in the destination country, rather migrants, may be perpetrators of violence. As a reaction to the arrival of foreign-born populations who may have left their country of origin due to unstable environments, anti-migration groups could stage acts of terrorism. Strictly speaking, this would count as diffusion of domestic terrorism via migration flows in the first place. Yet, the lack of coding in the data prevent us from a more thorough analysis, and this emphasizes again the need for more accurate coding and information on terrorist targets and perpetrators of violence. Finally, the diffusion of terrorism may not exclusively occur at one level, i.e., domestic-domestic or transnational-transnational. For instance, it would be difficult to imagine, in light of our theoretical framework why migrants would be a vehicle for the diffusion of international terrorism in their home country to their new state of residence. Instead, what may have been experienced at home could take both forms, transnational or domestic, and what then occurs in the new country of residence is characterized as domestic or transnational. The most comprehensive analysis against this background should thus not distinguish between domestic and transnational terrorism, which is how we designed the empirical analysis in the main text.

\section{A10. Short-term migration influx}

Our theory relies to some degree on the radicalization model in Sageman (2004, 2011). We thus focus our discussion on the radicalization of disaffected, marginalized, and dissatisfied migrant communities - i.e., migrants' 
experience in host states, which eventually implies that migrants are radicalized within destination states. However, according to the empirical analysis in the main text, we do not necessarily know whether terrorism diffuses because migrants are radicalized within destination states or if some of the already radicalized individuals migrate to destination states. Terrorism may diffuse from terror-prone countries because there is a larger portion of already-radicalized individuals within migrant stock from these countries.

In turn, an analysis on more short-term changes in the migration population should produce results that differ from those discussed in the main text. Against this background, Table A.8 summarizes a robustness check, where the spatial variables is now based on the yearly changes of the foreign-born population ('influx'), which captures more short-term mechanisms, including potentially those where migrants arrive in a state and then directly pursue terrorism there. As expected, though, we do not find much empirical support for this rationale in the analysis: the spatial lags on migration influx are statistically insignificant. Hence, although many policymakers, the media, or public institutions tend to emphasize the vulnerability to terrorism given short-term migrant influx, our results show that short-term migration fluctuations as captured by yearly changes in migration populations do not directly link to the threat of terrorism diffusion. Furthermore, cultural proximity only moderates the effects of long-term migrant trends as discussed in the main article.

Table VIII. Terrorism diffusion: Short-term migration influx

\begin{tabular}{lcc}
\hline & Model A15 & Model A16 \\
\hline Lagged dependent variable & $0.476^{* *}$ & $0.477^{* *}$ \\
Wy: Migrant inflow & $(0.030)$ & $(0.030)$ \\
& 0.005 & \\
Wy: Migrant inflow cultural proximity & $(0.007)$ & \\
& & -0.002 \\
Alliance with US & 0.123 & $(0.003)$ \\
& $(0.149)$ & 0.128 \\
Democracy & -0.004 & $-0.149)$ \\
& $(0.011)$ & $(0.011)$ \\
GDP per capita (ln) & -0.330 & -0.317 \\
& $(0.206)$ & $(0.207)$ \\
Population (ln) & $0.896^{\dagger}$ & $0.889^{\dagger}$ \\
& $(0.490)$ & $(0.491)$ \\
Total migration population & 0.005 & 0.005 \\
& $(0.018)$ & $(0.018)$ \\
Internal immigration policy restrictions & 0.144 & 0.087 \\
& $(0.497)$ & $(0.505)$ \\
Constant & -6.285 & -6.270 \\
& $(6.324)$ & $(6.329)$ \\
\hline Observations & 911 & 911 \\
Country fixed effects & Yes & Yes \\
Prob. $>$ F & Yes & Yes \\
\hline Staned effects & 0.000 & 0.000 \\
\hline
\end{tabular}

Standard errors in parentheses.

$\dagger \mathrm{p}<0.10, * \mathrm{p}<0.05, * * \mathrm{p}<0.01$ 


\section{A11. Negative binomial regression model}

The dependent variable is based on the natural logarithm of terrorist attacks, which we rely on to facilitate interpretation in the S-OLS environment. However, this has specific nonlinearity implications for the results and it is thus an effort worth making to re-estimate our main models using merely the number of terrorist attacks as the outcome variable. To this end, we also altered the temporally lagged dependent variable and the spatial lags. Finally, given the count nature of the revised outcome, a more appropriate estimator than OLS is the negative binomial regression model. Table A.9 presents the corresponding findings, but the substantive conclusions we can derive out of this table mirror the ones from the main models in the article.

Table IX. Terrorism diffusion: Negative binomial regression model

\begin{tabular}{lcc}
\hline & Model A17 & Model A18 \\
\hline Lagged dependent variable & $0.009^{* *}$ & $0.008^{* *}$ \\
& $(0.001)$ & $(0.001)$ \\
Wy: Migrant inflow & $0.048^{*}$ & \\
& $(0.019)$ & \\
Wy: Migrant inflow cultural proximity & & 0.005 \\
& & $(0.005)$ \\
Alliance with US & -0.050 & -0.226 \\
& $(0.325)$ & $(0.334)$ \\
Democracy & 0.025 & 0.010 \\
& $(0.021)$ & $(0.020)$ \\
GDP per capita (ln) & $-2.741^{* *}$ & $-2.572^{* *}$ \\
& $(0.472)$ & $(0.471)$ \\
Population (ln) & $3.567^{* *}$ & $3.242^{* *}$ \\
Total migration population & $(0.875)$ & $(0.871)$ \\
& $0.110^{* *}$ & $0.106^{* *}$ \\
Internal immigration policy restrictions & $(0.035)$ & $(0.035)$ \\
& 0.533 & 0.720 \\
Constant & $(0.979)$ & $(0.986)$ \\
& -6.796 & -4.997 \\
Observations & $(8.169)$ & $(8.239)$ \\
Country fixed effects & 911 & 911 \\
Prob. $>$ F & Yes & Yes \\
\hline Staned effects & Yes & Yes \\
\end{tabular}

Standard errors in parentheses.

$\dagger \mathrm{p}<0.10, * \mathrm{p}<0.05, * * \mathrm{p}<0.01$

\section{A12. Differences across culturally-close and distant dyads}

We focus on OECD states as targets of migration due to a large degree of homogeneity in several confounding factors. In addition, note our description of how cultural proximity is captured: Hofstede (1980) created ordinal scales for countries for each of these dimensions using standardized factor analysis of questionnaires administered between 1968 and 1972 - well before our data on migration, terrorism, or the explanatory variables were recorded. Yet, migrant-sending countries are all states in the world, and, ideally, our sample should comprise characteristics of immigrants from culturally different countries that are similar to the ones from culturally close 
states to tease out the impact of cultural proximity more clearly. We thus assess differences in core explanatory variables across culturally-close and distant dyads.

Table X. Differences in core explanatory variables: Culturally-close pairs of states

\begin{tabular}{lcc}
\hline & OECD receiver & Sender \\
\hline Terrorism $(\ln )$ & 1.565 & 1.487 \\
& $(1.530)$ & $(1.607)$ \\
GDP per capita $(\ln )$ & 9.730 & 8.845 \\
& $(0.794)$ & $(1.397)$ \\
Population $(\ln )$ & 16.883 & 16.903 \\
& $(1.244)$ & $(1.384)$ \\
Democracy & 8.138 & 4.207 \\
Total migration population (dyadic) & $(3.963)$ & $(7.118)$ \\
& 6.820 & - \\
\hline
\end{tabular}

Table entries are mean values of respective variable; standard deviation in parentheses.

Using the dichotomous specification of cultural proximity and distance, we compare in Tables A.10 and A.11 the most important variables of our model, i.e., terrorism, income, population, democracy, and migration across culturally close and distant pairs of states (OECD receiver combined with all sending states). The differences across groups for most items seem rather small to begin with, but they are less strongly pronounced for more culturally close sender-OECD receiver pairs. Despite these similarities, however, recall that we do not claim that culture on its own, or socio-economic distances that might be correlated with cultural proximity due to the way the former is operationalized via Hofstede (1980), may moderate the diffusion of terrorism across states. Only the combination with migration populations is of interest to us.

Table XI. Differences in core explanatory variables: Culturally-distant pairs of states

\begin{tabular}{lcc}
\hline & OECD receiver & Sender \\
\hline Terrorism (ln) & 1.298 & 0.897 \\
& $(1.417)$ & $(1.332)$ \\
GDP per capita $(\ln )$ & 10.020 & 7.616 \\
& $(0.773)$ & $(1.608)$ \\
Population (ln) & 16.501 & 15.921 \\
& $(1.399)$ & $(1.494)$ \\
Democracy & 8.844 & 1.387 \\
& $(3.189)$ & $(7.052)$ \\
Total migration population (dyadic) & 5.021 & - \\
& $(3.226)$ & - \\
\hline
\end{tabular}

Table entries are mean values of respective variable; standard deviation in parentheses.

\section{References}

Adamson, Fiona (2006) Crossing borders: International migration and national security. International Security 31(1): 165-199.

Alesina, Alberto; Arnaud Devleeschauwer; William Easterly; Sergio Kurlat \& Romain Wacziarg (2003) Fractionalization. Journal of Economic growth 8(2): 155-194. 
Benmelech, Efraim \& Esteban F Klor (2016) What Explains the Flow of Foreign Fighters to ISIS? National Bureau of Economic Research: Typescript.

Bove, Vincenzo \& Tobias Böhmelt (2016) Does immigration induce terrorism? Journal of Politics 78(2): $572-588$.

Cavalli-Sforza, Luigi L; Paolo Menozzi \& Alberto Piazza (1995) The History and Geography of Human Genes. Princeton, NJ: Princeton University Press.

Chenoweth, Erica (2013) Terrorism and democracy. Annual Review of Political Science 16: 355-378.

Dowty, Alan \& Gil Loescher (1996) Refugee flows as grounds for international action. International Security 21(1): $43-71$.

Enders, Walter; Todd Sandler \& Khusrav Gaibulloev (2011) Domestic versus transnational terrorism: Data, decomposition, and dynamics. Journal of Peace Research 48(3): 319-337.

Gaibulloev, Khusrav; James Piazza \& Todd Sandler (2017) Regime types and terrorism. International Organization 71(3): 491-522.

Gleditsch, Kristian (2007) Transnational dimensions of civil war. Journal of Peace Research 44(3): 293-309.

Guan, Weihua et al. (2003) From the help desk: Bootstrapped standard errors. Stata Journal 3(1): 71-80.

Hofstede, Geert (1980) Culture and organizations. International Studies of Management \& Organization 10(4): 15-41.

Kandogan, Yener (2012) An improvement to kogut and singh measure of cultural distance considering the relationship among different dimensions of culture. Research in International Business and Finance 26(2): $196-203$.

Kogut, Bruce \& Harbir Singh (1988) The effect of national culture on the choice of entry mode. Journal of International Business Studies 19(3): 411-432.

Marshall, Monty \& Keith Jaggers (2015) Polity IV project: Political regime characteristics and transitions, 1800-2014. Users' Manual. College Park, MD: University of Maryland.

Milton, Daniel; Megan Spencer \& Michael Findley (2013) Radicalism of the hopeless: Refugee flows and transnational terrorism. International Interactions 39(5): 621-645.

Özden, Çă̆lar; Christopher Parsons; Maurice Schiff \& Terrie Walmsley (2011) Where on earth is everybody? The evolution of global bilateral migration 1960-2000. World Bank Economic Review 25(1): 12-56.

Pickering, Jeffrey \& Emizet F Kisangani (2009) The international military intervention dataset: An updated resource for conflict scholars. Journal of Peace Research 46(4): 589-599. 
Putnam, Robert (2007) E pluribus unum: Diversity and community in the twenty-first century. Scandinavian Political Studies 30(2): 137-174.

Sageman, Marc (2004) Understanding terror networks. Philadelphia, PA: University of Pennsylvania Press.

Sageman, Marc (2011) Leaderless jihad: Terror networks in the twenty-first century. Philadelphia, PA: University of Pennsylvania Press.

Salehyan, Idean \& Kristian Gleditsch (2006) Refugees and the spread of civil war. International Organization $60(2): 335-366$.

Spolaore, Enrico \& Romain Wacziarg (2009) The diffusion of development. Quarterly Journal of Economics 124(2): 469-529.

Spolaore, Enrico \& Romain Wacziarg (2016) War and relatedness. Review of Economics and Statistics 98(5): 925-939.

Zhou, Y.-Y \& Andrew Shaver (2018) Do Refugees Spread Conflict? Princeton University, NJ: Typescript. 